\title{
Ancyronyx Erichson, 1847 (Coleoptera, Elmidae) from Mindoro, Philippines, with description of the larvae and two new species using DNA sequences for the assignment of the developmental stages
}

\author{
Hendrik Freitag $1,2, \dagger$
}

I Ateneo de Manila University, Department of Biology, School of Science \& Engineering, Loyola Heights, Quezon City 1101, the Philippines 2 Research Associate of Senckenberg Naturhistorische Sammlungen Dresden, Königsbrücker Landstrasse 159, D-01109 Dresden, Germany

† http://zoobank.org/8365AA9B-3DA5-4539-96EF-451BA4BAE2C4

Corresponding author: Hendrik Freitag (hfreitag@senckenberg.de)

Academic editor: C. Majka | Received 21 April 2013 | Accepted 29 July 2013 | Published 6 August 2013

http://zoobank.org/E3321643-4261-4F9A-9247-085B654D378E

Citation: Freitag H (2013) Ancyronyx Erichson, 1847 (Coleoptera, Elmidae) from Mindoro, Philippines, with description of the larvae and two new species using DNA sequences for the assignment of the developmental stages. ZooKeys 321: 35-64. doi: 10.3897/zookeys.321.5395

\begin{abstract}
Ancyronyx buhid sp. n. and A. tamaraw sp. n. are described based on adults and larvae, matched using their cox 1 or cob DNA sequence data. Additional records of $A$. schillhammeri Jäch, 1994 and A. minerva Freitag \& Jäch, 2007 from Mindoro are listed. The previously unknown larva of $A$. schillhammeri is also described here, aided by $\operatorname{cox} 1$ data. The new species and larval stages are described in detail and illustrated by SEM and stacked microscopic images. Keys to the adult and larval Ancyronyx species of Mindoro and an updated checklist of Philippine Ancyronyx species are provided. The usefulness as bioindicators, the phylogenetic relationships and biogeographic aspects affecting the distribution patterns are briefly discussed.
\end{abstract}

\section{Keywords}

Ancyronyx, Spider Water Beetles, Elmidae, Coleoptera, taxonomy, new species, larva, DNA barcoding, cox1, cob, Buhid, Mindoro, Philippines

Copyright Hendrik Freitag. This is an open access article distributed under the terms of the Creative Commons Attribution License 3.0 (CC-BY), which permits unrestricted use, distribution, and reproduction in any medium, provided the original author and source are credited. 


\section{Introduction}

The so-called spider water beetles of the genus Ancyronyx Erichson, 1847, family Elmidae Curtis, 1830 are known from North America, China, South and Southeast Asia (Freitag 2012). The genus diagnosis was recently revised (Freitag 2012) due to the description of several new species in the last decade.

The genus appears closely related to Podelmis Hinton, 1941 but can be distinguish by the complete absence of a prosternal anterior process, and the shape of the terminal segment of the ovipositor (stylus slender and more or less straight versus somewhat conical and distinctly bent laterad in Podelmis). Two morphologically distinct groups of Ancyronyx are recognised, both are characterised by varying morphological and ecological adaptation patterns. The SE Asian representatives of the $A$. variegatus group (sensu Freitag and Jäch 2007) of slightly larger species can be found in mesosaprobic rivers. The relatively smaller species of the $A$. patrolus group (sensu Freitag and Jäch 2007) occur predominantly in clean permanent streams (Freitag 2012). When identified on species level, they might therefore serve as good bioindicators, just as Elmidae in general (e.g. Moog and Jäch 2003, Hilsenhoff 1982). As larvae of the respective taxa are naturally more abundant then adults, appropriate identification tools for these developmental stages might be of great interest for ecological and applied limnological studies. Larval stages of Ancyronyx have been formally described only from the Philippines so far (Freitag and Balke 2011), but the larval habitus of the only North American species was figured by Brown (1972).

This study is part of the Baroc River Catchment Survey of the Ateneo de Manila University which focuses on the Key Biodiversity Area "69 Hinunduang Mt." (sensu Ong et al. 2002), classified as a terrestrial and inland water area of very high biological importance and extremely high critical conservation priority ("EHc"), under high socioeconomic pressure (Ong et al. 2002), which is, however, only subjected to moderate conservation efforts and not yet formally protected (Ambal et al. 2012).

Furthermore, previously collected specimens from Mindoro were included, that are partly from other conservation and research priority areas of high and highest urgency (“64 Naujan Lake National Park" and "62 Puerto Galera” sensu Ong et al. 2002).

\section{Material and methods}

\section{Taxon Sampling}

The material was preserved in 95\% ethyl alcohol to allow genetic sequencing. Most material was retrieved during the ongoing Baroc River Catchment Survey. Material collections from the 1990s were examined at the Naturhistorisches Museum Wien, Austria (NMW), the Senckenberg Museum für Tierkunde Dresden, Germany (SMTD), and the Zoological Museum of the University Copenhagen, Denmark (ZMUC). 
All specimens recorded by the first author were manually collected as indicated by letter " $\mathrm{M}$ " at the end of a collection label. Letter codes in parenthesis refer to a particular sampling station and microhabitat of the Baroc River Catchment. Number codes are arbitrary. They do not follow temporal or spatial patterns.

\section{DNA extraction and sequencing}

DNA was extracted from five larvae and three adults (entire specimens) from Mindoro, and one entire adult specimen of the recently described Ancyronyx jaechi Freitag, 2012 from Sri Lanka using Qiagen DNeasy kit (Qiagen, Hilden, Germany). The extraction was done by a single elution following the protocol for animal tissues (Qiagen 2002). The 3 ' end of the cytochrome $c$ oxidase subunit I ( $\operatorname{cox} I$ ) gene was amplified using polymerase chain reaction (PCR) following standard protocols (see http://zsm-entomology.de/wiki/ The_Beetle_D_N_A_Lab) and using primer pairs C1-J-2183 (5'-CAA CAT TTA TTT TGA TTT TTT GG-3'; Jerry) and TL2-N-3014 (5'-TCC AAT GCA CTA ATC TGC CAT ATT A-3'; Pat) (Simon et al. 1994) and Mango Taq DNA polymerase (Bioline, Luckenwalde, Germany). The PCR temperature progression was set: $30 \mathrm{~s}$ at $94^{\circ} \mathrm{C}, 30 \mathrm{~s}$ at $47^{\circ} \mathrm{C}, 60$ s at $72{ }^{\circ} \mathrm{C}(\times 35$ cycles $), 600$ s at $72^{\circ} \mathrm{C}$. Amplification products were purified with Qiagen Qiaquick PCR purification columns (Qiagen, Hilden, Germany). Cycle sequencing was performed as follows: $15 \mathrm{~s}$ at $96^{\circ} \mathrm{C}, 15 \mathrm{~s}$ at $50^{\circ} \mathrm{C}$, and $240 \mathrm{~s}$ at $60^{\circ} \mathrm{C}(\mathrm{x} 35$ cycles) using PCR primers with BigDye Terminator v3.1 Cycle Sequencing Kit (Applied Biosystems, Foster City, California, USA). The sequencing products were purified by ethanol precipitation $\left(25 \mu \mathrm{l}\right.$ of cold $\left(-20^{\circ} \mathrm{C}\right) 99 \%$ ethanol, $2.5 \mu \mathrm{l}$ of $3 \mathrm{M}$ sodium acetate added to product; centrifuged; washed with $25 \mu \mathrm{l}$ of $70 \%$ ethanol), and additionally with Agencourt CleanSEQ (Agencourt Bioscience, Beverly, Massachusetts, USA) following protocol 000600v32 (Agencourt Bioscience 2006) before electrophoresis.

The DNA extraction of three specimens was additionally used for the amplification a central part of the cytochrome b apoenzyme $(c o b)$ gene by using the primer pair 5'-GAG GAG CAA CTG TAA TTA CTA A-3' (CB3) and 5'-AAA AGA AA(AG) TAT CAT TCA GGT TGA AT-3' (CB4) (Baraclough et al. 1999). This was done to prove assignment of adult and larval stages of one species for which $\operatorname{cox} 1$ data were insufficient.

\section{Phylogenetic analysis}

Additional cox1 sequences of Philippine Ancyronyx species (Freitag and Balke 2011) previously submitted to ENA/GenBank (http://www.ebi.ac.uk/ena/) were included (see Table 1). The same applies for Podelmis viridiaenea Jäch, 1982 (Elmidae) from Sri Lanka that was used as outgroup. The newly amplified sequences were traced and aligned in CLUSTALW (Thompson et al. 1994) using BIOEDIT version 7.0.5.2. (Hall 1999) and default parameters. Phylogenetic analyses were conducted with MRBAYES vers. 3.1.2 (Ronquist et al. 
2012) using the GTR (General Time Reversible) model (Tavaré 1986) with default priors starting with random trees with three heated and one cold Markov chains. The analysis was run by 1,000,000 generations, and the first $25 \%$ of samples from the cold chain have been discarded as burnin. Branch support for the Bayesian trees was assessed with posterior probabilities determined via the $50 \%$ majority rule consensus. This easy analysis is only intended for matching larva and adults of the species treated in this paper.

\section{Morphological analysis}

Digital photographs were taken with an OLYMPUS SZ 61 stereo microscope (species habitus), and an OLYMPUS CX 21 compound microscope (dissected body parts), both with digital photo adapter LW Scientific MiniVID DCM 310. For each illustration a series of photographs taken at various focus layers was stacked using the stack function (species habitus) and corrected weighted average function (dissected body parts) of COMBINEZM software (Hadley 2008). The same optical systems we used for the dissection of adult specimens and the material examination. Biometric measurements were done by the use of a calibrated ocular micrometer.

Scanning electron microscope (SEM) images of vacuum dried material were obtained using a ZEISS EVO 50 XVP. Except for the single larval specimen of Ancyronyx schillhammeri, all specimens were coated with gold using one dissected and one entire specimen each.

For all larval material examined, measurements of the head capsule width are given in $\mathrm{mm}$ (e.g. $1 \mathrm{~L}(0.31)$ ) as a suitable indicator for the larval size and the instar stage assignment (see Freitag and Balke 2011).

Morphological terminology follows Kodada and Jäch (2005) and Freitag and Balke (2011).

\begin{tabular}{|c|c|}
\hline \multicolumn{2}{|c|}{ Abbreviations and repositories } \\
\hline Brgy. & Barangay (local government unit district) \\
\hline CL & calculated length (PL + EL) \\
\hline EL & elytral length \\
\hline EW & elytral width \\
\hline HW & head width \\
\hline ID & interocular distance \\
\hline $\mathbf{L}$ & larva / larvae \\
\hline M & manual collection \\
\hline MW & maximum pronotal width \\
\hline Oc. & Occidental \\
\hline Or. & Oriental \\
\hline PHIL & Philippines \\
\hline PL & pronotal length \\
\hline
\end{tabular}


sec.veget. surrounded by secondary vegetation

subm. submerged

CFM Collection Hendrik Freitag, Manila, Philippines, currently deposited at Ateneo de Manila University, Philippines

CZW Collection Herbert \& Salvacion V. Zettel, Vienna, Austria

NMW Natural History Museum Vienna, Austria

PNM Philippine National Museum Manila, Philippines

SMTD Senckenberg Museum of Zoology Dresden, Germany

ZMUC Zoological Museum of the University Copenhagen, Denmark

ZSM Zoological State Collections Munich, Germany

\section{Data resources}

The data underpinning the analysis reported in this paper are deposited at GBIF, the Global Biodiversity Information Facility, http://ipt.pensoft.net/ipt/resource. do?r=ancyronyx_mindoro_data

All DNA sequences were submitted to ENA/GenBank via online submission to EMBL-EBI. Accession numbers and curatory information are listed in Table 1.

Table I. ENA/GenBank accession numbers of DNA sequences, geographical origins, collection sites and organismic sample references of specimens used for molecular-genetic analyses.

\begin{tabular}{|c|c|c|c|c|c|c|}
\hline Species & Stage & Locality & Site & Voucher & $\operatorname{cox} 1$ & cob \\
\hline Ancyronyx jaechi Freitag, 2012 & adult & Sri Lanka & 1 & ZSM FR 027 & HF937369 & - \\
\hline Ancyronyx schillhammeri Jäch, 1994 & adult & Mindoro & $303 a$ & ZSM FR 029 & HF937371 & - \\
\hline Ancyronyx schillhammeri Jäch, 1994 & larva & Mindoro & $303 a$ & ZSM FR 030 & HF937370 & - \\
\hline Ancyronyx tamaraw Freitag & adult & Mindoro & 302 & ZSM FR 011 & HF937374 & - \\
\hline Ancyronyx tamaraw Freitag & larva & Mindoro & 302 & ZSM FR 012 & HF937373 & - \\
\hline Ancyronyx buhid Freitag & adult & Mindoro & 318 & ZSM FR 088 & - & HF937366 \\
\hline Ancyronyx buhid Freitag & arva & Mindoro & HR2g & ZSM FR 090 & HF937375 & HF937367 \\
\hline Ancyronyx buhid Freitag & arva & Mindoro & $310 \mathrm{a}$ & ZSM FR 091 & HF937376 & HF937368 \\
\hline $\begin{array}{l}\text { Ancyronyx minerva Freitag \& } \\
\text { Jäch, } 2007\end{array}$ & adult & Mindoro & $303 a$ & ZSM FR 033 & HF937372 & - \\
\hline $\begin{array}{l}\text { Ancyronyx minerva Freitag \& } \\
\text { Jäch, } 2007\end{array}$ & larva & Palawan & 159 & ZSM FR 025 & HE588180 & - \\
\hline $\begin{array}{l}\text { Ancyronyx helgeschneideri Freitag \& } \\
\text { Jäch, } 2007\end{array}$ & adult & Palawan & CR 4 & ZSM FR 007 & HE588167 & HE588183 \\
\hline Ancyronyx procerus Jäch, 1994 & & & 169 & ZSM FR 014 & HE588171 & HE588182 \\
\hline $\begin{array}{l}\text { Ancyronyx montanus Freitag \& } \\
\text { Balke, } 2011\end{array}$ & larva & Palawan & $16 \mathrm{~h}$ & ZSM FR 038 & HE588175 & - \\
\hline $\begin{array}{l}\text { Ancyronyx punkti Freitag \& } \\
\text { Jäch, } 2007\end{array}$ & adult & Palawan & 154 & ZSM FR 008 & HE588169 & - \\
\hline $\begin{array}{l}\text { Ancyronyx pseudopatrolus } \\
\text { Freitag \& Jäch, } 2007\end{array}$ & adult & Palawan & $16 f$ & ZSM FR 003 & HE588172 & - \\
\hline $\begin{array}{l}\text { Ancyronyx patrolus Freitag \& } \\
\text { Jäch, } 2007\end{array}$ & adult & Busuanga & 165 & ZSM FR 032 & HE588178 & - \\
\hline Podelmis viridiaenea Jäch, 1982 & adult & Sri Lanka & 1 & ZSM FR 035 & HE588181 & - \\
\hline
\end{tabular}




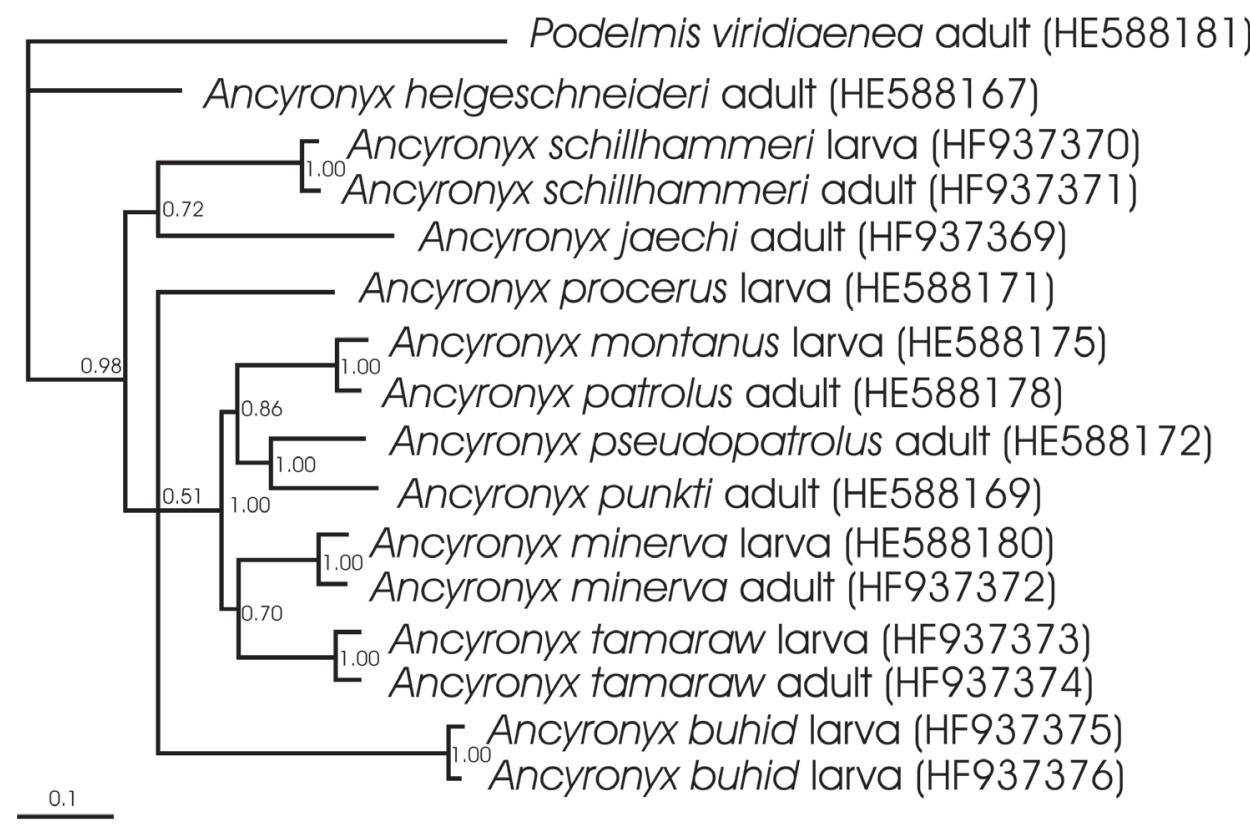

Figure I. Phylogram of the consensus tree of the Bayesian analysis with branch lengths measured in expected substitutions per site. Posterior probability values (printed when $>0.5$ ) at respective branches. Sample labels with developmental stage and ENA/GenBank code.

\section{Results}

\section{DNA sequence analysis}

Alignment of the $\operatorname{cox} 1$ data and trimming ambiguous bases at the 3 ' and 5 ' ends yielded a matrix of $804 \mathrm{bp}$. None of the sequences contained indels. The sequences of the larvae of $A$. buhid had nine ambiguous positions in-between which were coded as 'N's.

All adults and larvae could be matched unambiguously. Sequences of adult and larva of the same species from the same locality or island were identical or varied just in one base pair. Sequence samples of $A$. minerva from Mindoro diverged in eight base pair positions (six of them synonymous substitutions) from that of the same species from Palawan.

The sequencing of $\operatorname{cox} 1$ of the adults of $A$. bubid failed and is not included in the phylogenetic analysis. The cob sequences, however, which were amplified for two larvae and an adult of this species allowed unambiguous matching of the developmental stages. Their aligned and trimmed particial cob sequences of $350 \mathrm{bp}$ were identical except for four positions where a synonymous substitution was seen in one of either sequences.

A 50\% majority rule consensus trees based on $\operatorname{cox} 1$ data is illustrated in Fig. 1. All samples of the same species clustered together, supported by 1.0 posterior probability values. The species of the $A$. patrolus species group and its two subgroups respectively clustered together, however partly with lower posterior probability value support. $A$. bubid does not cluster with the $A$. patrolus group. 


\section{Taxonomy}

\section{Ancyronyx minerva Freitag \& Jäch, 2007}

http://species-id.net/wiki/Ancyronyx_minerva

Figs 2, 5

Ancyronyx minerva Freitag \& Jäch, 2007: 50-53 (adult description); Freitag and Pangantihon 2010: 133 (first record Mindoro); Freitag and Balke 2011: 53-58 (larva description), 79 (key); Freitag 2012: 63 (world check list).

Material examined. 1 \%, $6 \mathrm{~L}(0.22 ; 0.25,2 \times 0.29,0.31)$ (CFM) "PHIL.: Mindoro, Puerto Galera, NR km 37.2, downstr. Tamaraw Falls; riffle\&fall; rocks, woodlitter,roots; sec.veget.;c. $80 \mathrm{~m}$ asl., $13^{\circ} 27^{\prime} 03^{\prime \prime} \mathrm{N} 120^{\circ} 59^{\prime} 27^{\prime \prime} \mathrm{E} 22.4 .1994$, leg. Freitag (302)M"; 1 क [FR015], 1 ○े [FR033], 1 L (0.31) (ZSM) "PHIL.: Mindoro, San Teodoro, Tukuran Riv.; small lowld.riv.;riffle \&run; woodlitter, gravel; sec.veget.; c.30m asl., 13²5'34"N 120 58'37"E 23.4.1994, leg. Freitag (303a) M"; 1 đ (CFM) "PHIL.: Mindoro, Puerto Galera, NR km 59, downstr. Aninuan Falls; riffle; small mount. riv.,boulder,rocks,gravel,woodlitter; sec.veget.;c.80m asl., $13^{\circ} 29^{\prime} 10^{\prime \prime N} 120^{\circ} 54^{\prime} 18^{\prime \prime E ~ 24.4 .2009, ~ l e g . ~ F r e i t a g ~(304) M " ; ~} 1$ o pter., 2 L (0.21, 0.25 [FR079, FR080]) (ZSM) "PHIL.: Mindoro Oriental, Municipality Victoria, Brgy. Malayas, Malayas River; W Naujan tributary; sec. veget., submerged wood,

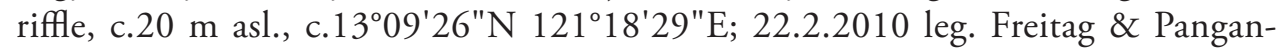
tihon (308a)M"; 1 §ิ pter. (CFM) "PHIL.: Mindoro Oriental, Bongabong, Brgy. Formon, Pastuhan, Tangisan Falls; deep mountain valley, sec. forest, submerged wood, riffle, c. $200 \mathrm{~m}$ asl., c. $12^{\circ} 43^{\prime} \mathrm{N} 121^{\circ} 23^{\prime} \mathrm{E}$; 27.10 .2011 leg. Freitag (318a)M"; 1 , 2 L (0.24 [FR087], 0.27) (ZSM, CFM) "PHIL.: Mindoro Oriental, Bongabong, Brgy. Formon, Pastuhan, Tangisan Falls; deep mountain valley, sec. forest, gravel \& boulders, riffle, c. $200 \mathrm{~m}$ asl., c. $12^{\circ} 43^{\prime} \mathrm{N} 121^{\circ} 23^{\prime} \mathrm{E} ; 27.10 .2011$ leg. Freitag (318)M"; 1 \& (CFM) "PHIL:Or.Mindoro, Roxas, Brgy. San Vicente, Baroc River; subm. wood; gravel flood plains; c. $12^{\circ} 37^{\prime} 07^{\prime \prime N} 121^{\circ} 24^{\prime} 06 " \mathrm{E}, 90 \mathrm{~m}$ asl; leg. Freitag 1 Apr.2013(BRf)M"; 1 Jె, 1 ᄋ (CFM) "PHIL:Or.Mindoro, Roxas, Brgy. San Vi-

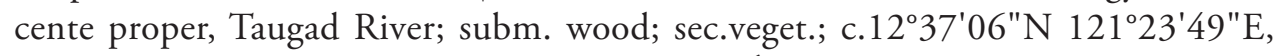
$100 \mathrm{~m}$ asl; leg. Freitag 2 Apr.2013(TR1f)M"; 1 đ, 1 क 3 L (0.29, $2 \times 0.31)(\mathrm{CFM})$ "PHIL: Or.Mindoro, Roxas, Brgy. San Vicente, Tauga River; rocks, riffle \& run; sec.veget.; c. $12^{\circ} 37^{\prime} 18^{\prime \prime} \mathrm{N} 121^{\circ} 22^{\prime} 58^{\prime \prime E}$, c.140m asl; leg. Freitag 17.11.2011(TR2g) M"; $1 \hat{0}, 1$,, $3 \mathrm{~L}(0.27,0.29,0.31)(\mathrm{CFM})$ : same locality and microhabitat "leg. Freitag \& Pangantihon 07.7.2012 (TR2g)M"; 1 \& (CFM) "PHIL:Or.Mindoro, Roxas, Brgy. San Vicente, Baroc River tributary Hiyong Creek; bottom gravel, run \& riffles; sec.veget.; c. $12^{\circ} 37^{\prime} 27^{\prime \prime} \mathrm{N} 121^{\circ} 22^{\prime} 48^{\prime \prime} \mathrm{E}, 147 \mathrm{~m}$ asl; leg. Pangantihon, 29.Jun.2012(THCc)M"; 2 L (0.24, 0.25) (CFM) "PHIL:Or. Mindoro, Roxas, Brgy. San Vicente, Baroc River tributary Hiyong Creek; subm. root packs, run;

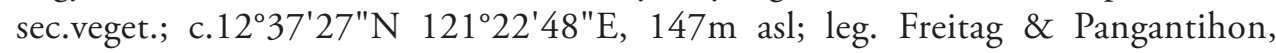
07.Jul.2012(THCh)M"; 1 L (0.31) (CFM) "PHIL: Or. Mindoro, Roxas, Brgy. 


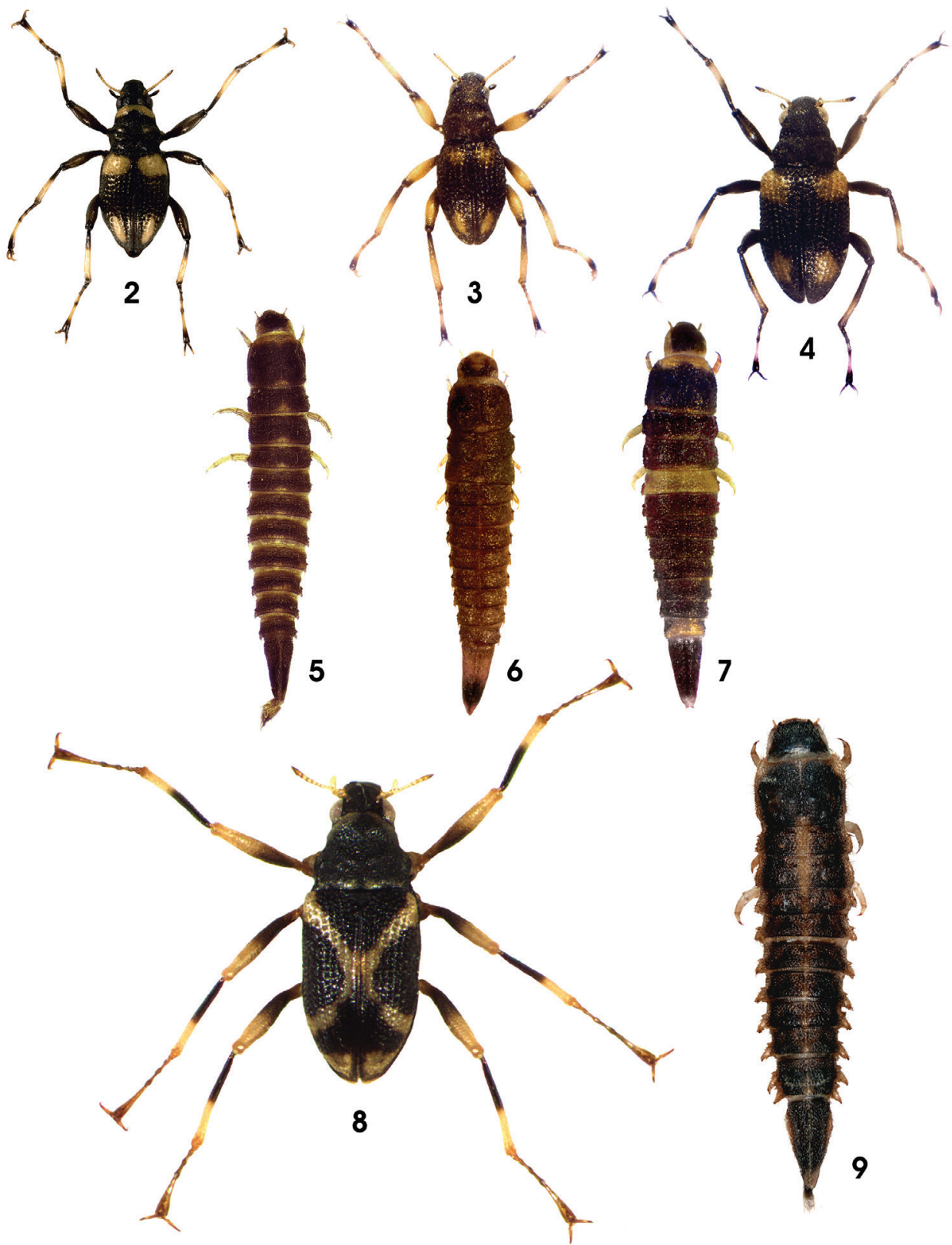

Figures 2-9. Habitus (not to scale) of $\mathbf{2}$ Ancyronyx minerva, adult $\mathbf{3}$ A. tamaraw, sp. n. adult $\mathbf{4}$ A. bubid, sp. n., adult 5 A. minerva, larva 6 A. tamaraw, sp. n., larva 7 A. buhid, sp. n., larva 8 A. schillhammeri, adult 9 A. schillhammeri, larva.

San Vicente, Sitio Quirao, Hinundugan tributary Quirao Buhay Creek; rocks, run; $12^{\circ} 36^{\prime} 10^{\prime \prime} \mathrm{N} 121^{\circ} 23^{\prime} 00^{\prime E} \mathrm{E}, 130 \mathrm{~m}$ asl; leg. Freitag \& Pangantihon, 30.06.2012 (HBCg)M". 
Distribution. The species is known from Busuanga, Mindoro and Palawan (Philippines) and is common on these islands.

Remarks. Morphological variations between the population of different islands are not evident, but the $\operatorname{cox} 1$ gene varies in a few more substitutional sites than within a population of one and the same island. The larva was described and illustrated in Freitag and Balke (2011).

Ecology. Both, adults and larvae, are usually collected from boulder and rock surfaces, or submerged rootpacks in run and riffle sections. The species is predominantly found in clean, small to medium sized permanent streams. (Freitag and Pangantihon 2010, Freitag and Jäch 2007).

\section{Ancyronyx tamaraw Freitag, sp. n.}

http://zoobank.org/9D03899B-56E5-4E7C-9C0E-A5154E30B2FC

http://species-id.net/wiki/Ancyronyx_tamaraw

Figs 3, 6, 10A-M, 11A-I, 12A-H

Etymology. This small and probably rare species is named in reference to its type locality, the Tamaraw Falls on the island of Mindoro. The tamaraw is a small Mindoroendemic buffalo. The term is used as noun in apposition.

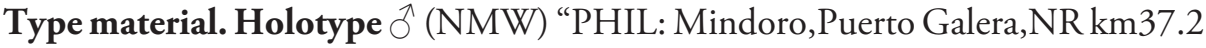
downstr. Tamaraw Falls; riffle\&fall; rocks, woodlitter, roots; sec.veget.; c.80m asl., $13^{\circ} 27^{\prime} 03^{\prime \prime N} 120^{\circ} 59^{\prime} 27^{\prime \prime E ~ 22.4 .1994, ~ l e g . ~ F r e i t a g ~(302) M ", ~ t e r m i n a l ~ p a r t s ~ o f ~ a b d o m e n ~}$

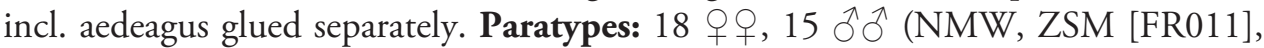
ZMUC, SMTD, CFM), 9 L (0.24, 0.28, $5 \times 0.29,2 \times 0.30)(Z S M$ [FR012], NMW, SMTD, CFM): same label data as holotype. 3 우우, 4 ô $\hat{\sigma}^{\lambda}$ (PNM): same locality data as holotype, leg. Freitag 11.2.2013.

Adult description. Body 1.2-1.5 mm long (CL + exposed portions of head \& tergit VIII); CL: $1.02-1.36 \mathrm{~mm}$; EW: 0.51-0.58 mm, CL/EW: 2.0-2.4.

Colouration as in Fig. 3: ventral side, coxae, trochanter, and pronotum brown; entire dorsal head capsule and mouthparts dark brown; elytra dark brown except for two pairs of yellow patches; anterior yellow elytral patches round, extending each between first and third row of elytral punctures, not reaching median or anterior elytral margin; posterior yellow elytral patches elongate-oval to subtriangular, not reaching median, lateral, and apical elytral margin; antennae yellow (except for dark tips and scape); legs dominantly yellowish except for coxa, trochanter and brown areas around all articulations, especially proximal and distal areas of femur, proximal third of tibia and distal third of fifth tarsomere.

HW $0.29-0.35 \mathrm{~mm}$; ID $0.15-0.18 \mathrm{~mm}$; labrum and distal portion of clypeus moderately densely micropunctate and covered with short trichoid setae (Fig. 10A); proximal portion of clypeus and frons microreticulate and punctate; frontoclypeal suture inconspicuous, slightly convex. Eyes slightly protruding. Antennae (Fig. 10B) with 11 antennomeres, slender, c. as long as head wide. Genae (Fig. 10D) rugose and 


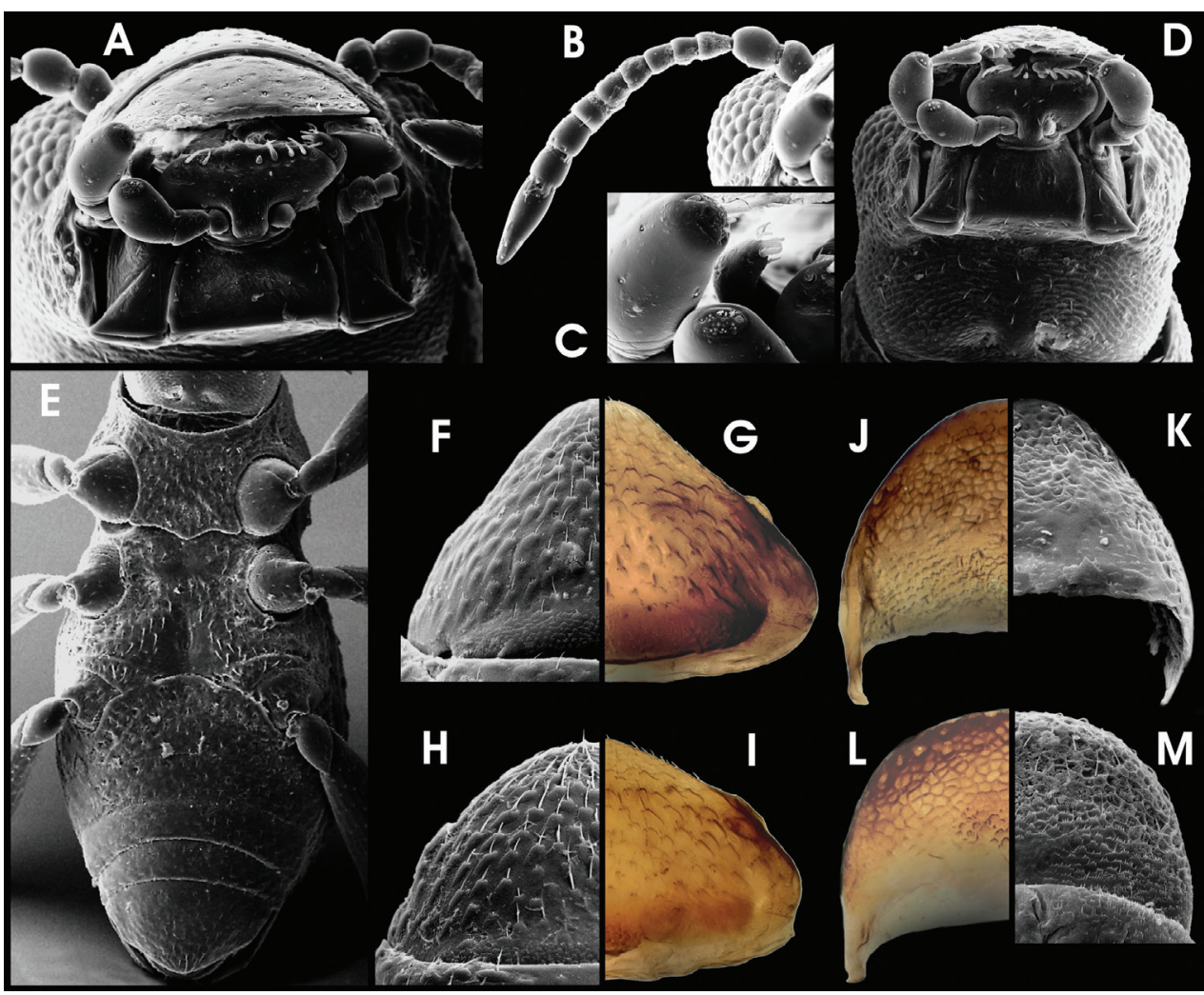

Figure 10. Ancyronyx tamaraw Freitag, sp. n., (SEM photographs in greyscale, stereo microscope photographs in colour; not to scale: see respective chapter for size measurements); adult male: $\mathbf{A}$ head, frontal $\mathbf{B}$ antenna, frontal $\mathbf{C}$ maxillary and labial palpi, frontal $\mathbf{D}$ head, ventral $\mathbf{E}$ throax and abdomen, ventral; adult female: F, G ventrite 5, ventral; adult male: $\mathbf{H , ~ I ~ v e n t r i t e ~ 5 , ~ v e n t r a l ; ~ a d u l t ~ f e m a l e : ~ J , ~ K ~ t e r g i t e ~ V I I I , ~}$ dorsal; adult male: $\mathbf{L}, \mathbf{M}$ tergite VIII, dorsal.

reticulate, with indistinct pubescence. Gula (Fig. 10D) with somewhat regularly arranged striae except for central portion, moderately densely pubscent; gular sutures absent. Mandible with bilobed tip. Maxilla (Fig. 10A) with very short cardo; stipes with distinct flat, triangular elevation ventrally; galea palp-like elongate, with apical setae and sensilla (Fig. 10C); lacinia not examined. Labium (Fig.10A) with subtrapezoidal postmentum, prementum suboval, undivided, with subapical row of ten short trichoid setae; labial palps three-segmented, c. as long as postmentum, with apical setae and sensilla (Fig. 10C).

Pronotum (Fig. 3) $0.35-0.38 \mathrm{~mm}$ long (PL), $0.38-0.41 \mathrm{~mm}$ wide (MW), inconspicuously wider than long (PL/MW), widest at about posterior 0.4 , distinctly narrower than elytra, with moderately deep transverse groove; anteriorly of transverse groove slightly vaulted; posterior portion medially elevated; posterolateral oblique grooves small and round, but conspicuous; lateral margin distinctly arcuate; anterior margin convex; pronotal surface entirely microreticulate and with moderately densely 
arranged seta-bearing tubercles; lateral pronotal carina absent; hypomeron inconspicuously reticulate. Prosternum (Fig. 10E) punctate; prosternal process broadly subpentagonal, distinctly wider than long, almost flat.

Metascutellum subcordiform, medially slightly impressed, micropunctate. Elytra (Fig. 3) elongate, $0.78-0.98 \mathrm{~mm}$ long (EL), c. 1.5-1.7 times as long as wide (EL/ EW), laterally arcuate (broadest at about anterior 0.45 ), anteriorly slightly roundly convergent, posteriorly roundly convergent to apices, with eight longitudinal, moderately impressed rows of punctures (counted at level of metacoxae); median rows more regular than lateral ones; five strial rows between suture and humerus; punctures large and moderately deeply impressed; interstices and intervals convex, granulose to microreticulate; lateral elytral gutter very narrow, inconspicuous; humeri broadly rounded; elytral apices separately rounded. Mesoventrite (Fig. 10E) short, micropunctuate, with a round median impression and a sublateral pair of round elevations. Metaventrite (Fig. 10E) comparably small; medial impression wide, not conspicuously longitudinal, rather a shallow, funnel-like round impression deepest at median posterior margin; disc with scattered inconspicuous setose tubercles, glabrous in-between. Anepisternum 3 microreticulate with additional scattered punctures. No hind wings present in all specimens examined.

Legs (Fig. 3) slightly longer than body; coxae large; pro- and mesocoxae (Fig. 10E) subglobular (drop-shaped), lateral portion visible in dorsal view; metacoxae (Fig. 10E) rather conically elevated from a flat base, not visible in dorsal view; trochanter (Fig. $10 \mathrm{E})$ small, broadly lanceolate, invisible in dorsal view; femora and tibiae with microsetiferous tubercles; tibiae distally with few trichoid setae; each tarsomere with ventral pair of short trichoid setae; claws moderately wide, rather short (compared to other $A n$ cyronyx species), strongly bent, base of each with two teeth, distal one distinctly larger.

Ventrite 1 (Fig. 10E) distinctly arcuately projected anteriad; medioanterior portion depressed (connecting to funnel-like metaventrite impression). Ventrites 2-4 (Fig. 10E) with small, moderately densely arranged punctures; surface between punctures glabrous; tubercles larger and denser toward lateral declivity; ventrite 5 (Figs $10 \mathrm{~F}-\mathrm{I})$ moderately densely covered with short adpressed setae emerging from flat tubercles; lateral projection inconspicuous.

Aedeagus (Figs 11A-D) $410 \mu \mathrm{m}$ long, somewhat similar to that of $A$. sophiemarie Jäch, 2004 (see Jäch 2004: figs 3-4), but phallobase longer and apical area of median lobe distinctly wider. Phallobase almost symmetrical, more or less straight, except for tapered and ventrally bent base, slightly longer ventrally, with conspicuous, strongly sclerotised ventral and lateral margins. Median lobe moderately long and wide (c. 70 $\mu \mathrm{m})$, straight, evenly and slightly tapering towards apex up to apical 0.2 of median lobe, then moderately bent ventrad and more abruptly tapering into a wide apical area; apex pointing ventrad, with numerous pore-like structures on dorsal side; basolateral (penile) apophyses short, not overreaching paramere base; ventral sac distinct, ventrally protruding (Fig. 11C), internal portion speckled, moderately sclerotised (Fig. 11B). Fibula weakly sclerotised; corona inconspicuous. Parameres short, c. $145 \mu \mathrm{m}$ long, reaching about basal 0.7 of aedeagus, elongately subtriangular, widely separated 


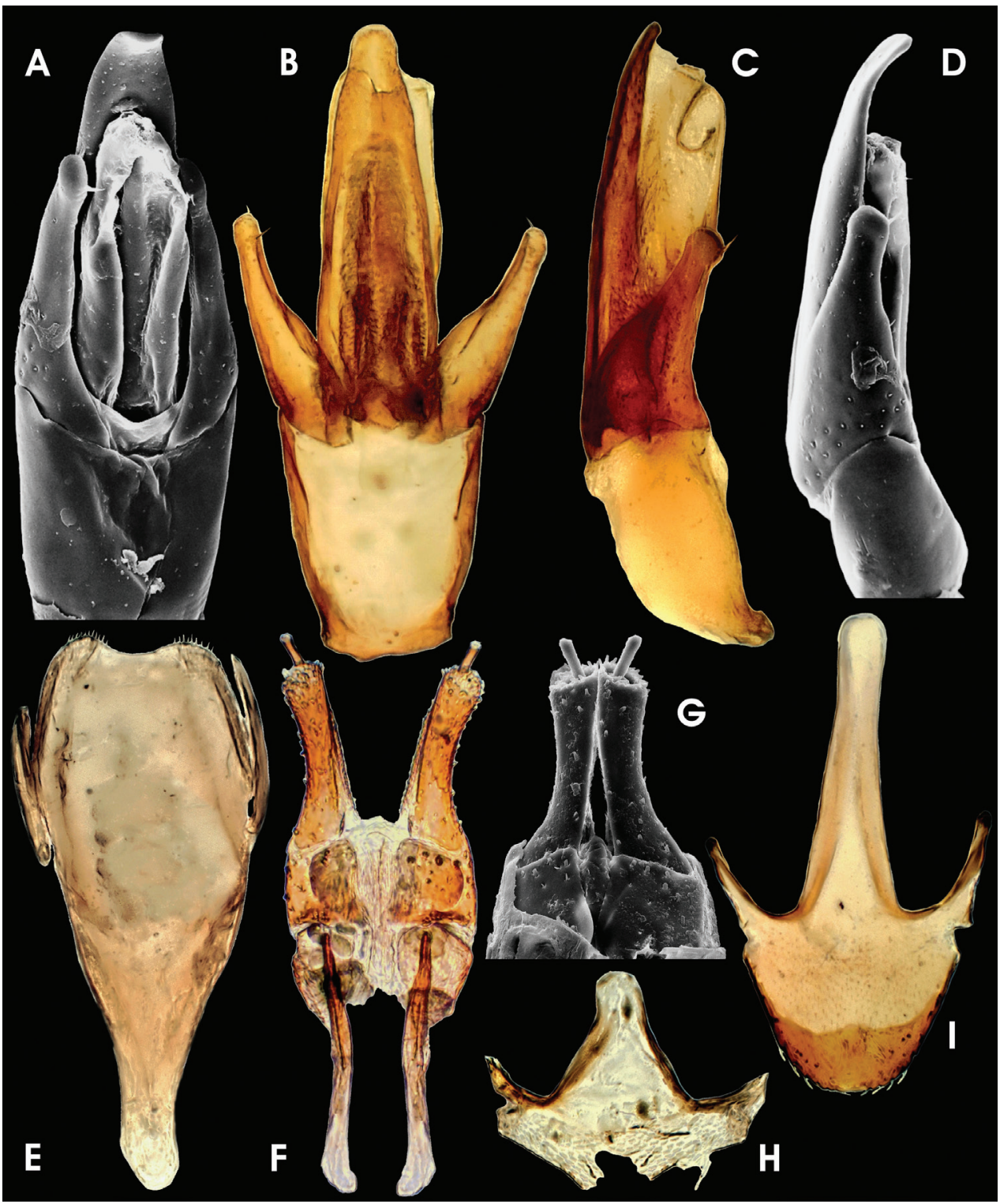

Figure I I. Ancyronyx tamaraw Freitag, sp. n., (SEM photographs in greyscale, stereo microscope photographs in colour; not to scale: see respective chapter for size measurements); adult male: $\mathbf{A}$ aedeagus, ventral $\mathbf{B}$ aedeagus, dorsal C, D aedeagus, lateral $\mathbf{E}$ sternite IX, ventral; adult female: $\mathbf{F}, \mathbf{G}$ ovipositor, ventral; adult male: $\mathbf{H}$ sternite VIII, ventral; adult female: I sternite VIII, ventral.

ventrally; laterobasal margin emarginate (Fig. 11D) apical portion roundly widened, narrowest subapically, with few short setae (two apical, two medio-subapical).

Sternite IX (Fig. 11E), c. $380 \mu \mathrm{m}$ long, with short anterior strut, not clearly partitioned from apical portion; apical corners rounded, with patches of micro-setae, apical margin broadly emarginate; longer paraproct reaching apical margin. 
Ovipositor (Fig. 11F, G) c. $480 \mu \mathrm{m}$ long. Stylus slender, rather staight, with various sensilla. Coxite long, outer margin curved, distal portion with several rather short and broad, peg-like spines, most densely set subapically at lateral margins; inner margin pubescent; basal portion with similar, slightly slenderer, peg-like spines; near valvifer insertation with dense patch of very small spines. Valvifer as long as coxite; fibula distinctly bent and widened caudally.

Secondary sexual characters: Sternite VIII in male (Fig. 11H) short, weakly sclerotised and with very short median strut; in female (Fig. 11I) distinctly longer, slightly more sclerotised than in male, apical corners broadly rounded and with small seate, median portion with dense micro-pubescence (not conspicuous in males). Tergite VIII in female (Figs 10J, K) long, subtriangular, slightly longer than broad (c. $220 \mu \mathrm{m}$ long, $210 \mu \mathrm{m}$ wide), with few moderately short setae (apical ones widest), condyles large and conspicuous. Tergite VIII in male (Figs 10L, M) subsemicircular, distinctly wider than long and shorter than in female (c. $180 \mu \mathrm{m}$ long, $225 \mu \mathrm{m}$ wide); in apical half with moderately long setae. Ventrite 5 in female (Figs 10F, G) subtriangular (c. $250 \mu \mathrm{m}$ long, $360 \mu \mathrm{m}$ wide); in male (Figs 10H, I) similar in general shape, but slightly shorter (c. $210 \mu \mathrm{m}$ long, $370 \mu \mathrm{m}$ wide) and rounder.

Adult differential diagnosis. Ancyronyx tamaraw superficially resembles A. sophiemarie from Sibuyan and $A$. minerva. The new species can be easily distinguished by the combination of elytral colour pattern (anterior yellow elytral patches circularly round, not reaching median or anterior elytral margin; posterior patches elongate-oval to subtriangular), the predominantly yellowish legs, the brown (not black) pronotum and head, and it's aedeagus with wide and flat apical portion.

Larval diagnosis (based on sixth instar). Colour (Fig. 6) similar to that of Ancyronyx minerva (see Freitag and Balke 2011: figs 3, 11A-L), but most distinctly different by anterior median head portions (clypeus, anterior frons) pale; anterior yellow pronotal band small, limited to very most anterior portion; at least pro-, meso-, metanotum with small circular-round (not broadly subtriangular) yellow pattern at medioposterior margin; abdominal segment IX with pale yellowish apex and a conspicuous dark pattern extending c. posterior 0.2-0.4; abdominal segment IX relatively longer than in larvae of $A$. minerva.

HW $0.29 \mathrm{~mm}$; entire larva about $2.7 \mathrm{~mm}$ long. Body elongate very similar in the external characters to that of $A$. minerva, except for the following: Posterolateral projections (Figs 12A, F) of all abdominal segments short, generally not overreaching posterior segment margins.

Head (Figs 6, 12B-D) with subparallel lateral margins posterior 0.1-0.7, moderately tapering anteriad; lateral setae long; a dorsolateral pair of moderately long single setae present (Fig. 12B). Frontal suture distinctly V-shaped. Labrum subtrapezoidal. Antennae (Figs 12C, D) c. 1/4 as long as head; peduncle at with at least one faciculate seta; pedicel c. two times as long as scape, c. three times as long as wide. Maxillary stipes (Fig. 12D) slightly tapering towards apex. Labial mentum (Fig. 12D) narrowest basal; lateroapical pair of spines rather small, positioned at distal edge.

Pro-, meso-, metathorax and legs (Figs 6, 12E) almost as in $A$ minerva. Pronotum with rather inconspicuous small round signa (glabrous areas) in posterior half. Ventral sclerites of thorax (Fig. 12E) rugulose, not glabrous. 


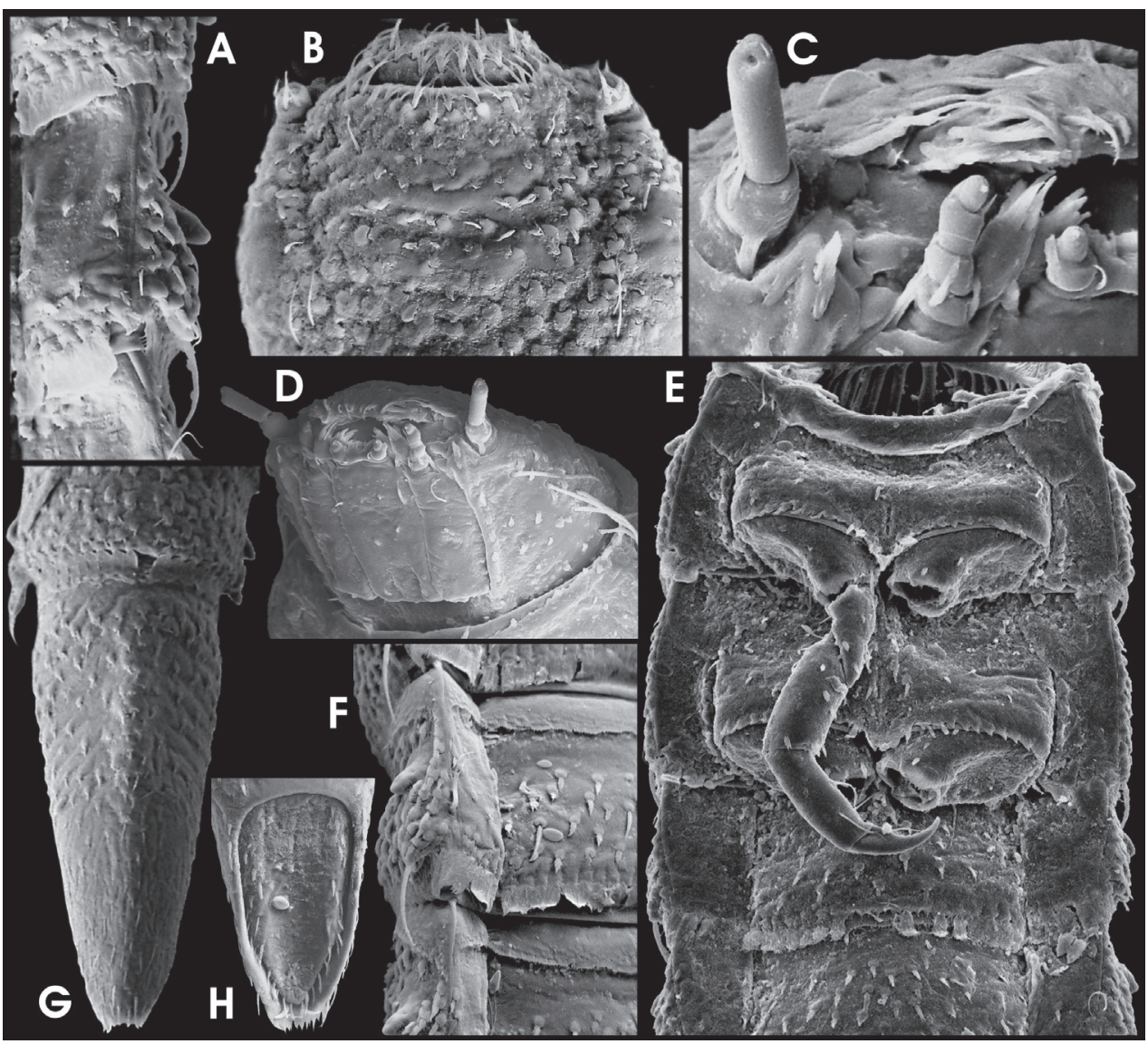

Figure 12. Ancyronyx tamaraw Freitag, sp. n., larva (SEM photographs; not to scale): A detail of abdominal segment III, lateral, with posterolateral projections and spiracles $\mathbf{B}$ head, dorsal $\mathbf{C}$ head, frontal $\mathbf{D}$ head, ventrolateral $\mathbf{E}$ meso- and metathoracic and first and second abdominal segments, ventral F lateral parts of median sclerites of abdominal venter, with setiferous tubercles and lateral projections G abdominal segments VIII and IX, dorsal $\mathbf{H}$ operculum, ventral.

Abdomen (Figs 6, 12A, E-H) without conspicuous dorsosagittal carinae except for the anterior half of segment IX (Fig. 12G); squamose setae at posterior rim of segments I-VIII large (Figs 12E, F). Ventral sclerites of segment I with distinct sagittal ridge in anterior half, reaching c. $1 / 2$ to $2 / 3$ of segment length. Apex of segment IX (Fig. 12G) emarginate (sometimes inconspicuous due to apical setae). Operculum (Fig. 12H) longer than in $A$. minerva (more than double as long as wide).

Larval differential diagnosis. The species can most easily be distinguished from A. minerva which looks superficially most similar by the partly pale colour pattern of the dorsal head, the narrower circular medioposterior pale pattern at pro-, meso-, and metanotum and the longer last abdominal segment with pale apical area and distinctly dark subapical portion. 
Variation between larval instars. The final and prefinal instar stages available for this study do not vary conspicuously except for their size.

Distribution. The species is known from the type locality in north-eastern Oriental Mindoro. Additional material that appears conspecific is known from Subic, Zambales, Luzon and Bohol (unpublished material at CFM and NMW).

Ecology. The specimens were collected in well oxygenated water from rock surfaces, submerged woodlitter and roots in run and riffle sections of the stream below Tamaraw Falls. Since all examined material comes from this, in fact clean and almost natural small mountain river, any detailed conclusion about the habitat and ecological requirements would be highly speculative. It is, however, surprising that not any single specimen was found at any other collection site in Mindoro so far.

\section{Ancyronyx bubid Freitag, sp. n.}

http://zoobank.org/C731192C-EF06-4BDD-A387-9AB967DC9FED

http://species-id.net/wiki/Ancyronyx_buhid

Figs 4, 7, 13A-P, 14A-I

Etymology. The species is named for the indigenous ethnic group of the Buhid in whose ancestral areas it commonly occurs. Same time, their kind support and care during regular field trips of faculty members and students of the Ateneo de Manila University's Biology Department to the their Ancestral Domain should be honoured. Buhid is used as noun in apposition.

Type material. Holotype $\widehat{\overbrace{}}$ (NMW) "leg. Jäch 1.12. \ PHILIPPINEN - Mindoro \20km W Calapan $1992 \backslash$ Hidden Paradise (21)", terminal parts of abdomen

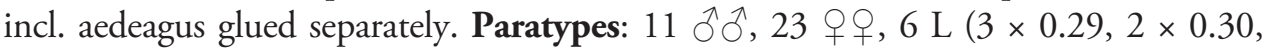
0.31) (NMW): same data as holotype. $8 \mathrm{~L}(2 \times 0.29,0.30,4 \times 0.31,0.32)(\mathrm{NMW})$ "PHILIPPINEN - Mindoro $\backslash 20 \mathrm{~km}$ W Calapan $1992 \backslash$ Hidden Parad. 20.-21.11. \leg. Jäch(10)"; 4 qq "PHILIPPINEN - Mindoro $\backslash 20 \mathrm{~km} W$ Calapan $1992 \backslash$ Hidden Parad.

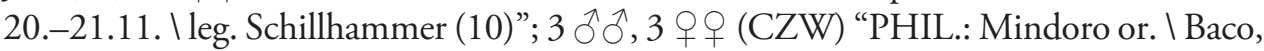

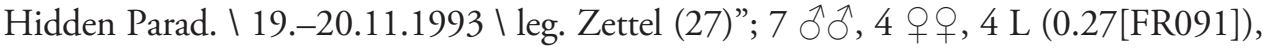
$2 \times 0.31,0.29$ ) (SMTD) "PHIL.: Mindoro, Baco, Dulangan, Lantuyan torrent mount. Riv.; sec.veget.; riffle, wood debris, c. $55 \mathrm{~m}$ asl., c. $13^{\circ} 16^{\prime} 08^{\prime \prime N} 121^{\circ} 04^{\prime} 56^{\prime \prime E ~ 02.4 .2000, ~}$ leg. Freitag (310a)M"; 1 ภ, 3 우 (PNM, ZSM [FR088]) "PHIL.: Mindoro Oriental, Bongabong, Brgy. Formon, Pastuhan, Tangisan Falls; deep mountain valley, sec. for-

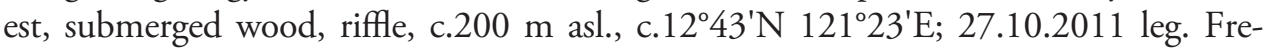
itag (318)M"; 11 L (0.22, 0.24, 0.25, $6 \times 0.31,2 \times 0.32)$ (CFM) "PHIL:Or.Mindoro, Roxas, Brgy. San Vicente, Tauga River; rocks, riffle \& run; sec.veget.; c. $12^{\circ} 37^{\prime} 18^{\prime \prime} \mathrm{N}$ $121^{\circ} 22^{\prime} 58^{\prime \prime E}$, c.140m asl; leg. Freitag 17.3.2012(TR2g)M"; 1 § [FR086] (ZSM), 4 L $(0.21,0.24,0.29,0.31)$ (CFM) "PHIL:Or.Mindoro, Roxas, Brgy. San Vicente, Tauga River; rocks, riffle \& run; sec.veget.; c. $12^{\circ} 37^{\prime} 18^{\prime \prime} \mathrm{N} 121^{\circ} 22^{\prime} 58^{\prime \prime E}$, c. $140 \mathrm{~m}$ asl; leg. Fre-

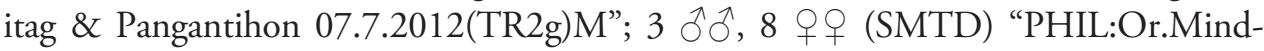




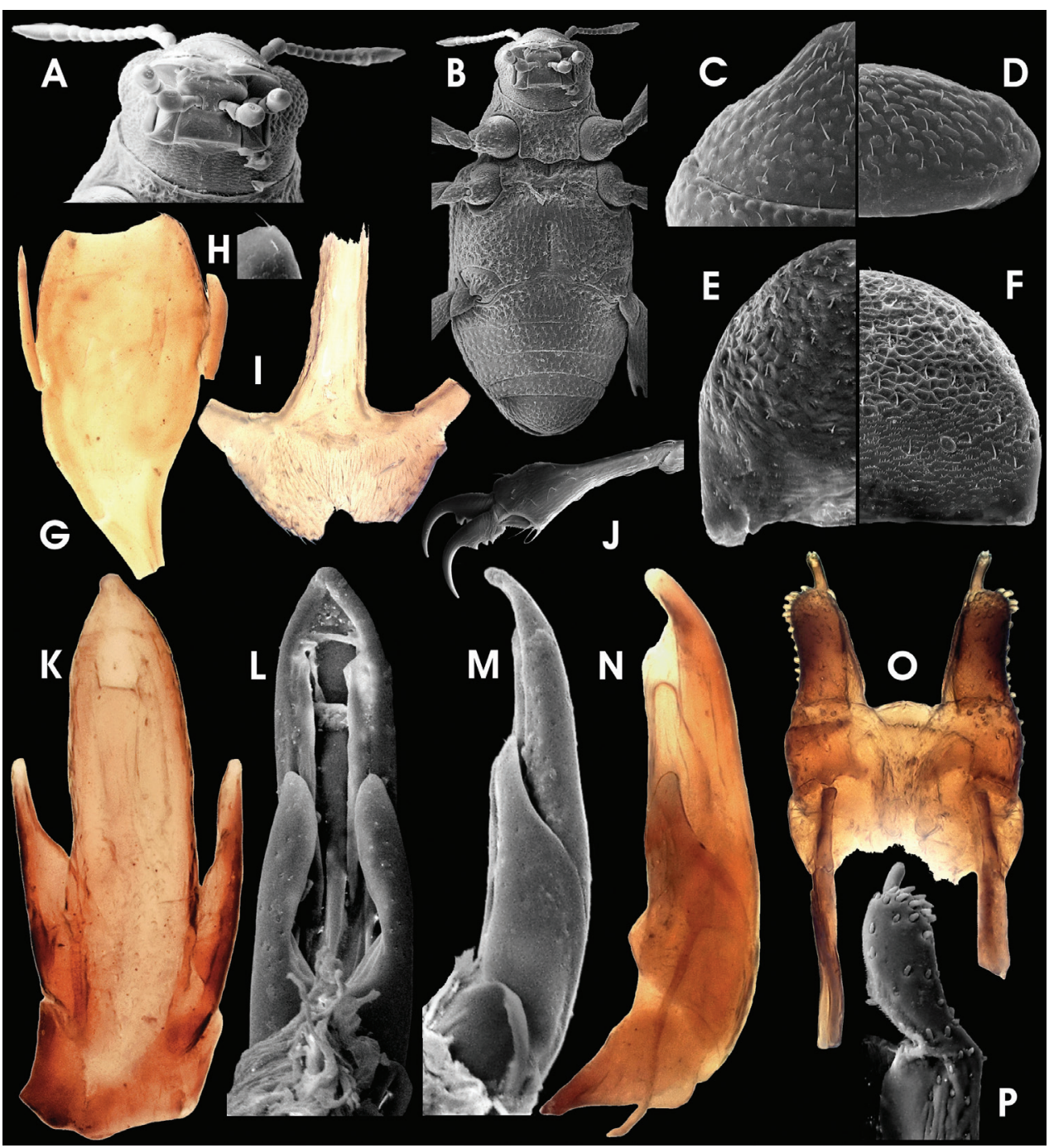

Figure 13. Ancyronyx buhid Freitag, sp. n., (SEM photographs in greyscale, stereo microscope photographs in colour; not to scale); adult male: $\mathbf{A}$ head, ventral $\mathbf{B}$ entire body, ventral $\mathbf{C}$ adult female: ventrite 5, ventral; adult male: D ventrite 5, ventral; adult female: E tergite VIII, dorsal; adult male: $\mathbf{F}$ tergite VIII, dorsal G sternite IX, ventral; aedeagus, ventral; adult female: I sternite VIII, ventral; adult male: J proximal tarsal segment, lateral $\mathbf{K}$ aedeagus, dorsal $\mathbf{L}$ aedeagus, ventral; $\mathbf{M}, \mathbf{N}$ aedeagus, lateral $\mathbf{E}$ adult female: $\mathbf{O}, \mathbf{P}$ ovipositor, ventral.

oro, Roxas, Brgy. San Vicente, Tauga River; subm. wood, run; sec.veget.; c. $12^{\circ} 37^{\prime} 18^{\prime \prime} \mathrm{N}$

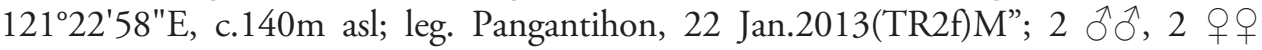
(ZSM) "PHIL:Or.Mindoro, Roxas, Brgy. San Vicente, Sitio Tauga Diit, Baroc River tributary Tauga Diit; subm. wood, run \& riffle; sec.veget.; $12^{\circ} 37^{\prime} 32^{\prime \prime N} 121^{\circ} 21^{\prime} 17^{\prime \prime} \mathrm{E}$, $180 \mathrm{~m}$ asl; leg. Freitag \& Pangantihon, 05.Feb.2012(TIRf)M"; 2 q $q$ (CFM) "PHIL:Or. Mindoro, Roxas, Brgy. San Vicente, Baroc River tributary Hiyong Creek; side pool, lit- 
toral sand and gravel; sec.veget.; c. $12^{\circ} 37^{\prime} 27^{\prime \prime} \mathrm{N} 121^{\circ} 22^{\prime} 48^{\prime \prime E}, 147 \mathrm{~m}$ asl; leg. Freitag \& Pangantihon, 05.Feb.2012(THCe)M"; 6 L (0.22, $2 \times 0.24,0.27,2 \times 0.31)$ (NMW) "PHIL:Or.Mindoro, Roxas, Brgy. San Vicente, Baroc River tributary Hiyong Creek; subm. root packs, run; sec.veget.; c. $12^{\circ} 37^{\prime} 27^{\prime \prime} \mathrm{N} 121^{\circ} 22^{\prime} 48^{\prime \prime E}, 147 \mathrm{~m}$ asl; leg. Freitag

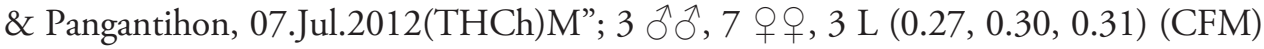
"PHIL:Or.Mindoro, Roxas, Brgy. San Vicente, Sitio Tauga Diit, Baroc River tributary Tauga Daka; subm. wood in run; sec.veget.; c. $12^{\circ} 37^{\prime} 56^{\prime \prime} \mathrm{N} 121^{\circ} 20^{\prime} 33^{\prime \prime E}$, c.350m asl; leg. Freitag, 4 Apr. 2013 (TDR2f)M"; 15 ふึે, 14 우 (NMW) "PHIL:Or.Mindoro, Roxas, Brgy. San Vicente, Sitio Tauga Diit, Baroc River tributary Tauga Daka; subm. wood in run; sec.veget.; c. $12^{\circ} 38^{\prime} 05^{\prime \prime N} 121^{\circ} 19^{\prime} 33^{\prime \prime E}$, c. $530 \mathrm{~m}$ asl; leg. Pangantihon, 18

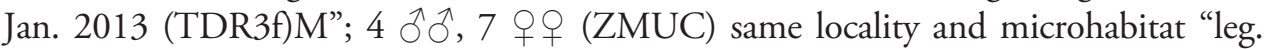

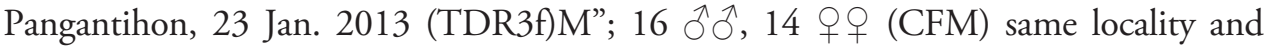
microhabitat "leg. Pangantihon, 15 Feb. 2013 (TDR3f)M"; 3 q $, 2,2$ L (0.27, 0.34) (PNM) "PHIL:Or.Mindoro, Roxas, Brgy. San Vicente, Sitio Tagaskan, Hinundugan River,; rocks, run; sec.veget.; c. $12^{\circ} 35^{\prime} 22^{\prime \prime} \mathrm{N} 121^{\circ} 21^{\prime} 54^{\prime \prime E}$, c.200m asl; leg. Freitag \& Pangantihon,20.12.2011(HR2g)M"; 4L (0.25 [FR090], 0.26, $2 \times 0.31,0.32)$ (ZSM): same locality and microhabitat "leg. Freitag \& Pangantihon,06.Feb.2012(HR2g)M"; 2 ふึ่, 5 우 (CFM) "PHIL: Or. Mindoro, Roxas, Brgy. San Vicente, Sitio Tagaskan, Hinundungan River; subm. wood, run c. $12^{\circ} 36^{\prime} 30^{\prime \prime N} 121^{\circ} 22^{\prime} 38^{\prime \prime E}$, c. $200 \mathrm{~m}$ asl; leg. Pangantihon; 31 Mar. 2013(HR3f)M"; 6 ふึَ, 1 ㅇ, 9 L $(2 \times 0.24,2 \times 0.27,3 \times 0.30,2 \times$ 0.33) (CFM) "PHIL: Or. Mindoro, Roxas, Brgy. San Vicente, Sitio Tagaskan, Hinundungan River; rocks, riffle \& run; c. $12^{\circ} 36^{\prime} 30^{\prime N} 121^{\circ} 22^{\prime} 38^{\prime E}$, c.200m asl; leg. Freitag; 31 Mar. 2013(HR3g)M"; 3 L (0.24, 0.25, 0.31) (CFM) "PHIL: Or. Mindoro, Roxas, Brgy. San Vicente, Sitio Quirao, Hinundugan tributary Quirao Buhay Creek; rocks, run; $12^{\circ} 36^{\prime} 10^{\prime \prime} \mathrm{N} 121^{\circ} 23^{\prime} 00^{\prime \prime E}, 130 \mathrm{~m}$ asl; leg. Freitag \& Pangantihon, 30.06.2012 (HBCg) M"; 1 L (0.30) (CFM) "PHIL: Or. Mindoro, Roxas, Brgy. San Vicente, Hinundugan

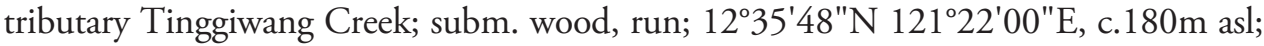
leg. Freitag; 31 Mar.2013 (HTCf)M". Other material: 1 ๙ (CFM) "PHIL:Or.Mindoro, Roxas, Brgy. San Vicente, Tauga River; subm. wood, run; sec.veget.; c. $12^{\circ} 37^{\prime} 18^{\prime \prime} \mathrm{N}$ $121^{\circ} 22^{\prime} 58^{\prime \prime E, ~ c .140 m ~ a s l ; ~ l e g . ~ F r e i t a g ~ 28 . N o v .2011 ~(T R 2 f) M " . ~}$

Adult description. Body $1.4-1.6 \mathrm{~mm}$ long $(\mathrm{CL}+$ exposed portions of head \& tergit VIII); CL: 1.25-1.38 mm; CL/EW: 1.9-2.1. Colouration as in Fig. 4: entire dorsal head capsule, mouthparts, pronotum, and elytra (except for two pairs of yellow patches) black; anterior yellow elytral patches extending from humeri mediad approximately up to second row of elytral punctures, not reaching median elytral margin; posterior yellow elytral patches oval, not reaching median, lateral, and apical elytral margin; ventral side, coxae, trochanter, femur, proximal half of tibia, areas around tibial and tarsomere articulations, and claws brown; at least distal half of tibia and proximal portion of fifth tarsomere yellowish; antennae yellow (except for dark tips and basal segment).

Head (Figs 4, 13A) 0.33-0.36 mm wide (HW); ID 0.19-0.21 mm; labrum smooth, with moderately densely trichoid pubescence; clypeus (except for anterior margin) and frons with longitudinal striae on microreticulate ground, moderately 
densely covered with short trichoid setae; frontoclypeal suture straight and conspicuous. Eyes slightly protruding. Antennae (Fig. 13A) with 11 antennomeres, slender, slightly shorter than head width. Genae (Fig. 13A) reticulate, with indistinct pubescence. Gula (Fig. 13A) with regularly arranged, scale-like striae (including median portion), with inconspicuous pubscens; gular sutures absent. Mouthparts (Fig. 13A) almost as in A. tamaraw except for shorter postmentum, that is rather sub-rectangular than trapezoidal; prementum with subapical row of eight very short trichoid setae; labial palps three-segmented, slightly longer then postmentum.

Pronotum (Fig. 7) $0.36-0.40 \mathrm{~mm}$ long (PL), 0.42-0.44 mm wide (MW), slightly wider than long (PL/MW), widest at about posterior 0.3 , distinctly narrower than elytra, with deep transverse groove; anteriorly of transverse groove slightly vaulted; posterior portion broadly vaulted; posterolateral oblique grooves divided (two pairs), elongate, conspicuous; lateral margin distinctly arcuate; anterior margin distinctly convex; pronotal surface entirely microreticulate and rugose, with inconspicuous pubescence; lateral pronotal carina absent; hypomeron as pronotal surface. Prosternum (Fig. 13B) transverse, prosternal process broadly subpentagonal, distinctly wider than long, both appearing rugose by microreticulation superimposed with irregularly shaped setiferous tubercles.

Metascutellum subcordiform, micropunctate. Elytra (Fig. 4) broadly elongate, 0.89-0.98 mm long (EL), 0.61-0.66 mm wide (EW), c. 1.4-1.5 times as long as wide $(\mathrm{EL} / \mathrm{EW})$, almost parallel-sided in anterior $0.1-0.65$, anteriorly slightly convergentposteriorly roundly convergent to apices, with c. nine longitudinal, moderately impressed rows of punctures (counted at level of metacoxae); median rows rather inconspicuous; lateral rows more regular and more deeply impressed than median rows; six to seven strial rows between suture and humerus; punctures moderately large and moderately deeply impressed, lateral punctures deeper than median ones; interstices and intervals granulose to micropunctate; lateral elytral gutter narrow; humeri roundly obtuse; elytral apices inconspicuously separately rounded.

Mesoventrite (Fig. 13B) very short, most anteriorly micropunctuate, posteriorly granulose, with deeply impressed median longitudinal impression. Metaventrite (Fig. 13B) large, without glabrous areas, entirely microreticulate superimposed with irregularly shaped setiferous tubercles; the latter appearing reticulately connected in lateral portions; tubercles smaller and shallower at disc; median longitudinal impression deeply impressed, laterally extending into a subtriangular groove; groove without setiferous tubercles. Anepisternum 3 microreticulate with one row of punctures. Hind wings present in all specimens examined, venation not examined.

Legs (Figs 4, 13B, J) approximately as long as body, or very little shorter; coxae large, only procoxae visible in dorsal view; pro- and mesocoxae (Fig. 13B) subglobular (drop-shaped); metacoxae (Fig. 13B) rather obtuse and shallowly elevated, obliquely conoidal; trochanter (Fig. 13B) short, broadly lanceolate, not visible in dorsal view, distal end distinctly pointed; femora and tibiae appearing longitudinally striated by dense cover with very elongate, micro-setiferous tubercles; tibiae distally with rather short and inconspicuous setae; tarsomeres with small scattered setae (Fig. 13J), most 
conspicuous at ventral side and near claw insertation; claws (Fig. 13J) large, rather slender, strongly bent; base of each with three teeth, distal one very large (mutilated in specimen figured in 13J).

Ventrite 1 (Fig. 13B) arcuately projected anteriad between hind coxae; microreticulate and tuberceliferous as in metaventrite especially near anterior margin. Ventrites 2-4 (Fig. 13B) with evenly distributed, subcordiform, setiferous tubercles; interstices almost glabrous; ventrite 5 (Figs 13C, D) evenly covered with short adpressed setae emerging from subcordiform tubercles; lateral projection shallow.

Sternite IX (Figs 13G, H) c. $340 \mu \mathrm{m}$ long, with moderately long anterior strut (distal end broken off in specimen figured in 13G), apical corners rounded, each with one lateroapical seta and one inconspicuous sublateroapical seta; apical margin slightly broadly emarginate; longer paraproct almost reaching apical margin.

Aedeagus (Figs 13K-N) similar to that of Ancyronyx minutulus (see Freitag and Jäch 2007: figs 15a, b), but distinctly larger (c. $350 \mu \mathrm{m}$ long), relatively stouter and without long setae. Median lobe moderately long and moderately slender, with few indistinct pores, subapically straight, not widened, c. $90 \mu \mathrm{m}$ wide, apically distinctly curved ventrad (lateral view, Figs $13 \mathrm{M}, \mathrm{N}$ ); tip rounded; ventral sac weakly sclerotised except for lateral rim (Figs $13 \mathrm{~K}, \mathrm{M}$ ); fibula weakly sclerotised, inconspicuous in transillumination; corona inconspicuous. Phallobase asymmetrical, bent lateroventrad, distinctly longer ventrally, with conspicuous, strongly sclerotised margins; basolateral (penile) apophyses inconspicuous; ejaculatory duct well scleotised and conspicuous in transillumination. Parameres elongately subtriangular, rather short, reaching about basal 0.67 of aedeagus, almost contiguous ventrally, subapically slightly widened ventrad; apices with one apical and one subapical very short setae (Figs 13K, M); basal margin oblique and not conspicuously emarginate (lateral view, Figs 13M, N).

Ovipositor (Fig. 13O, P) c. $410 \mu \mathrm{m}$ long. Stylus slender, rather staight, with various apical sensilla. Coxite moderately stout, distinctly shorter than in specimens of the Ancyronyx patrolus species group, but longer than in those of the $A$. variegates group; outer margin concave; all over with several rather short and broad, peg-like spines, increasing in size and density apically at lateral margins; inner margin pubescent; basal portion short. Valvifer moderately longer than coxite; fibula slightly curved.

Secondary sexual characters: Sternite VIII in male short, weakly sclerotised and with very short median strut; in female (Fig. 13I) distinctly longer, more sclerotised than in male medially emarginate; apical corners rounded and with small seate; median portion with dense micro-pubescence. Tergite VIII in female (Fig. 13E) subtriangular, almost as long as wide (c. $210 \mu \mathrm{m}$ long, $230 \mu \mathrm{m}$ wide), with few moderately short setae; condyles large and conspicuous. Tergite VIII in male (Fig. 13F) subsemicircular, distinctly wider than long (c. $170 \mu \mathrm{m}$ long, $230 \mu \mathrm{m}$ wide), shorter than in female, reticulate; apical half with moderately short setae. Ventrite 5 in female (Fig. 13C) subtriangular (c. $230 \mu \mathrm{m}$ long, $400 \mu \mathrm{m}$ wide); in male (Fig. 13D) broadly oval and distinctly shorter (c. $180 \mu \mathrm{m}$ long, $370 \mu \mathrm{m}$ wide).

Adult differential diagnosis. In its colour patterns, Ancyronyx buhid resembles $A$. patrolus, $A$. punkti and especially $A$. pseudopatrolus from Palawan. The new species can 
be easily distinguished by the combination of body morphometric and genital characters (body, especially abdomen and elytra, relatively wider (CL/EW c. 2.0; EL/EW c. 1.45) than in other species; legs not distinctly longer than body; coxite of ovipositor moderately stout; aedeagus with straight main piece (not widened subapically), almost contiguous parameres ventrally, very short and few parameral setae.

Larval diagnosis (based on sixth instar). Colour (Fig. 7) dorsally dominantly dark brown except for yellow lateral head, clypeus and labrum, most anterior portion of pronotum and the almost entire first abdominal segment; most specimens additionally with yellowish to pale brown (preterminal) abdominal segment VIII (at least posterior portion) and apex of abdominal segment IX (up to c. posterior 0.15). Legs, mouthparts, ventral head, thorax, and abdomen yellowish to pale brown, but some specimens with darker brown thoracic venter and ventral abdominal segment IX.

HW $0.31 \mathrm{~mm}$; entire larva about $3.1 \mathrm{~mm}$ long. Body elongate, wider than that of $A$. minerva and $A$. tamaraw, but similar in the external characters, except for the following: posterolateral projections (Figs 7, 14A) of abdominal segments II-VI usually reaching or slightly overreaching posterior segment margins. Lateral rim of thorax and abdomen with scattered long, trichoid setae. Dorsal sagittal line slightly impressed from prothorax to abdominal segment $\mathrm{V}$ and without tubercles.

Head (Figs 7, 14B-E) widest posterior 0.3, not subparallel in posterior half, dorsolaterally with a pair of moderately long setae and one pair near the frontoclypeal suture (Fig. 14B); lateral setae of various size, very short to moderately long. Frontal suture inconspicuous; subbasal fringe of clypeus with rather short fasciculate setae. Ventral side (Fig. 14D) dominantly rugulose; basolateral areas and genae (inbetween setae) glabrous (Fig. 14C).

Antenna as in Figs 14D, E, c. 1/4 as long as head; scape setae fasciculate; pedicel long; flagellum and sensorium subequal in length.

Labrum (Fig. 14B) with subapical fringe of ramose setae and few lateral trichoid setae. Maxilla (Fig. 14D) with parallel-sided stipes; maxillary palpus (Figs 14D, E) slightly slenderer than in A. tamaraw. Labial mentum (Fig. 14D) with lateral margin slightly sinuously curved (concave in posterior half), narrowest at basal 0.2; pair of trichoid setae moderately short (reaching anterior margin), inserted sublaterally at anterior 0.2; pair of subapical lateral setae fasciculate; subbasal pair of setae ramous. Submentum short, not clearly partitioned from somewhat protruding semicircular ligula which is conspicuously covered with setiform microstructures (Fig. 14D); labial palpi as in A. tamaraw.

Pro-, meso-, metathorax and legs (Figs 7, 14F) almost as in A. minerva. Pronotum with rather inconspicuous small round signa (glabrous areas) in posterior half. Ventral sclerites of thorax (Fig. 14E) rugulose, not glabrous; venter of metathorax with conspicuous sagittal tuberculate ridge (similar to that of the venter in abdominal segment I).

Abdomen (Figs 7, 14A, H, I) without conspicuous dorsosagittal carina except for the anterior half of segment IX (Fig. 12G); squamose setae at posterior rim of segments I-VIII large (Figs 14A, H). Ventral sclerite of segment I with distinct sagittal ridge in anterior half (Fig. 14F), reaching c. $1 / 2$ to $2 / 3$ of segment length. Apex of segment 


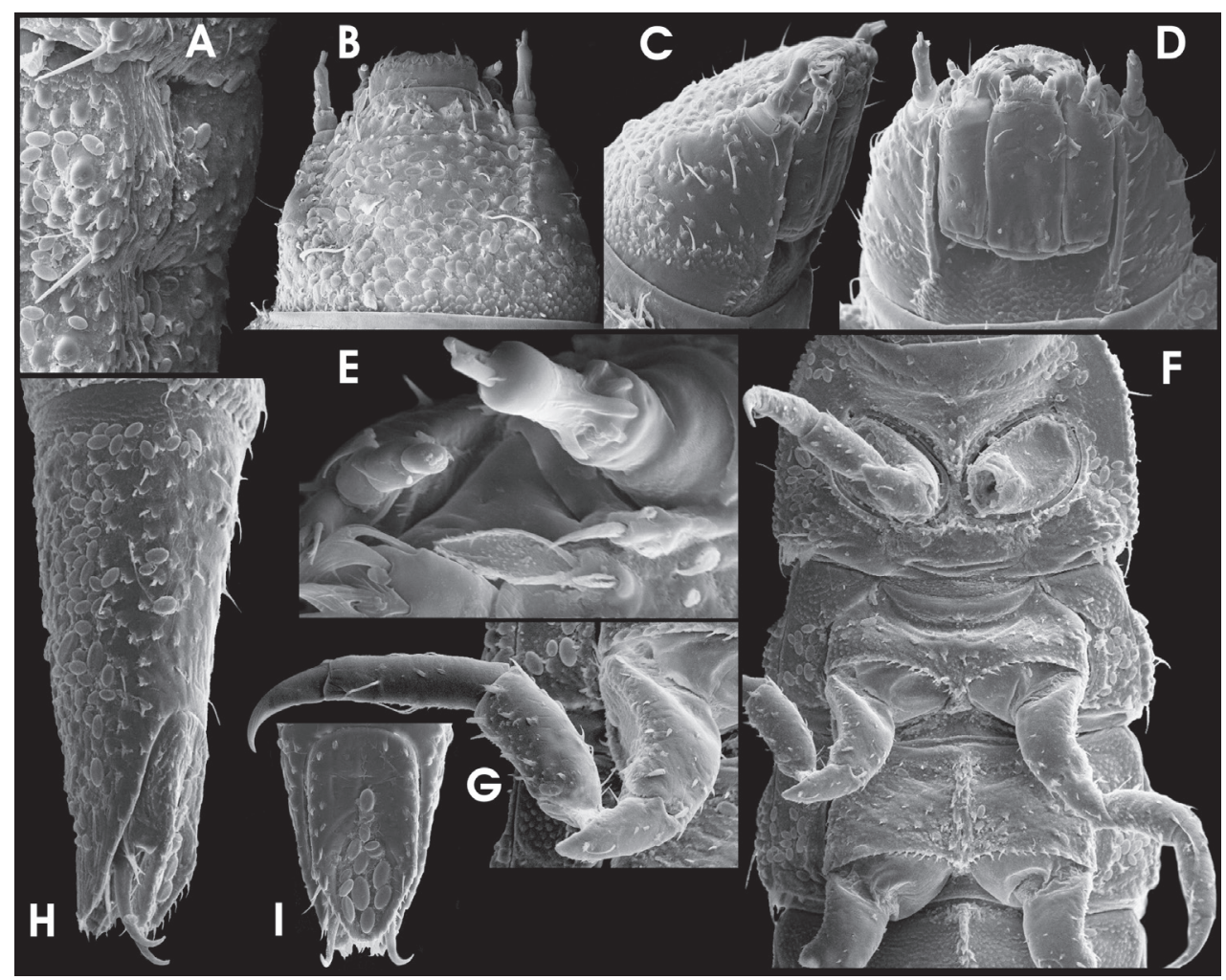

Figure 14. Ancyronyx buhid Freitag, sp. n., larva (SEM photographs; not to scale): A detail of abdominal segment VII, lateral, with posterolateral projections and spiracles $\mathbf{B}$ head, dorsal $\mathbf{C}$ head, lateral $\mathbf{D}$ head, ventral $\mathbf{E}$ antenna, frontal $\mathbf{F}$ thoracic and first abdominal segments, ventral $\mathbf{G}$ midleg, ventral $\mathbf{H}$ abdominal segment IX, lateral I operculum, ventral.

IX emarginate (sometimes inconspicuous due to apical setae). Operculum (Fig. 14I) almost twice as long as wide, basal portion glabrous.

Variation between larval instars. The available prefinal instar specimens vary only slightly from the description above, namely by the relatively slenderer thoracic and abdominal segments, the smaller and rather inconspicuous spiracles near the posterolateral projection, the slightly broader legs with fewer setae, and the relatively longer lateral setae on thorax and abdomen.

Larval differential diagnosis. The species can most easily be distinguished from any other known Ancyronyx larva by the obviously pale first abdominal segment. The general shape and the proportions of the larva of this species resemble those of the $A$. patrolus group, from which it can be additionally distinguished by the anterior yellow band, that is medially narrower (not extended as in several species of the $A$. patrolus group) and the character combination of long sagittal crest of the first abdominal segment venter, slightly impressed dorsosagittal line without protruding tubercles. From the species of the $A$. variegatus group, this larva can be distinguished easily 
by its spindle-shape habitus (subsemicircular in cross section) and the rather short posterolateral appendages.

Distribution. Known only from Mindoro Island where this new species was recorded from various streams in the province of Oriental Mindoro.

Ecology. Both, adult and larvae of Ancyronyx bubid occur in medium sized, unpolluted rivers in mountainous areas. This suggests an affinity to undisturbed habitats. The relatively highest abundances were found on submerged wood and rough rock surfaces in runs and riffles. Some root packs and partly submerged grass bunches in riffles were also found to be densely colonised with the species. Much more rarely it was found among bottom gravels in runs and calm pools, where specimens were possibly just shifted by drift.

Remarks. One male specimen from site "TR2f" varies in regard to the primary and secondary sexual characters, namely the length of tergite VIII, ventrite 5 and aedeagus. Since all other characters do not differ from the type material, this is regarded as an abnormality caused during pupation.

\section{Ancyronyx schillhammeri Jäch, 1994}

http://species-id.net/wiki/Ancyronyx_schillhammeri

Figs $8,9,15 \mathrm{~A}-\mathrm{H}$

Ancyronyx schillhammeri Jäch, 1994: 617-619 (adult description), Freitag and Pangantihon 2010: 133-137 (faunistic records).

Material examined. 1 [FR029], 1 L (0.61 [FR030]) (ZSM) "PHIL.: Mindoro, San Teodoro, Tukuran Riv.; small lowld.riv.;riffle \&run; woodlitter, gravel; sec.veget.;

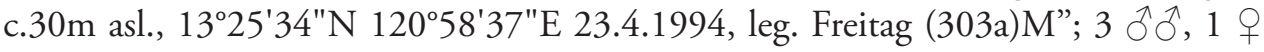
(PNM) "PHIL.: Mindoro Oriental, Bongabong, Brgy. Formon, Pastuhan, Tangisan Falls; deep mountain valley, sec. forest, submerged wood, riffle, c. $200 \mathrm{~m}$ asl., c. $12^{\circ} 43^{\prime} \mathrm{N}$ $121^{\circ} 23^{\prime} \mathrm{E} ; 27.10 .2011 \mathrm{leg}$. Freitag (318a)M"; 3 $\widehat{\partial}$ (CFM) "PHIL:Or.Mindoro, Roxas, Bagumbayan, polluted Magugo River; sec.veget.; submerges wood, run; $6 \mathrm{~m}$ asl., c. $12^{\circ} 35^{\prime} 27^{\prime \prime N ~ 121^{\circ} 31^{\prime} 00 " E ; ~ 05.6 .2000 ~ l e g . ~ F r e i t a g ~ \& ~ P a n g a n t i h o n ~(329 c) M " ; ~} 1$ ภ, 4 우우 (CFM) "PHIL:Or.Mindoro, Roxas, Brgy. San Vicente, Baroc River; subm. wood;

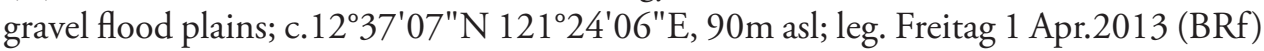

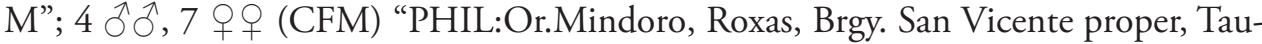
gad River; subm. wood; sec.veget.; c. $12^{\circ} 37^{\prime} 06^{\prime N} 121^{\circ} 23^{\prime} 49^{\prime \prime E}, 100 \mathrm{~m}$ asl; leg. Freitag

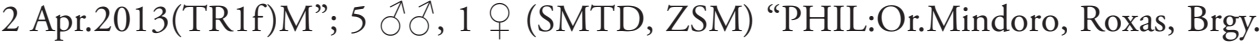

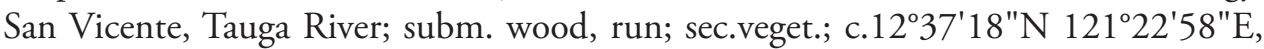
c.140m asl; leg. Freitag 28.Nov.2011(TR2f)M"; 1 ð’, 3 우 (ZMUC) "PHIL:Or.Mindoro, Roxas, Brgy. San Vicente, Sitio Tauga Diit, Baroc River tributary Tauga Daka; subm. wood in run; sec.veget.; c. $12^{\circ} 38^{\prime} 05^{\prime \prime N} 121^{\circ} 19^{\prime} 33^{\prime \prime E}$, c.530m asl; leg. Pangantihon, 23 Jan. 2013 (TDR3f)M"; 1 (CFM) "PHIL:Or.Mindoro, Roxas, Brgy. San Vicente, Sitio Quirao, Baroc River tributary Hinundugan River; subm. wood; c. 


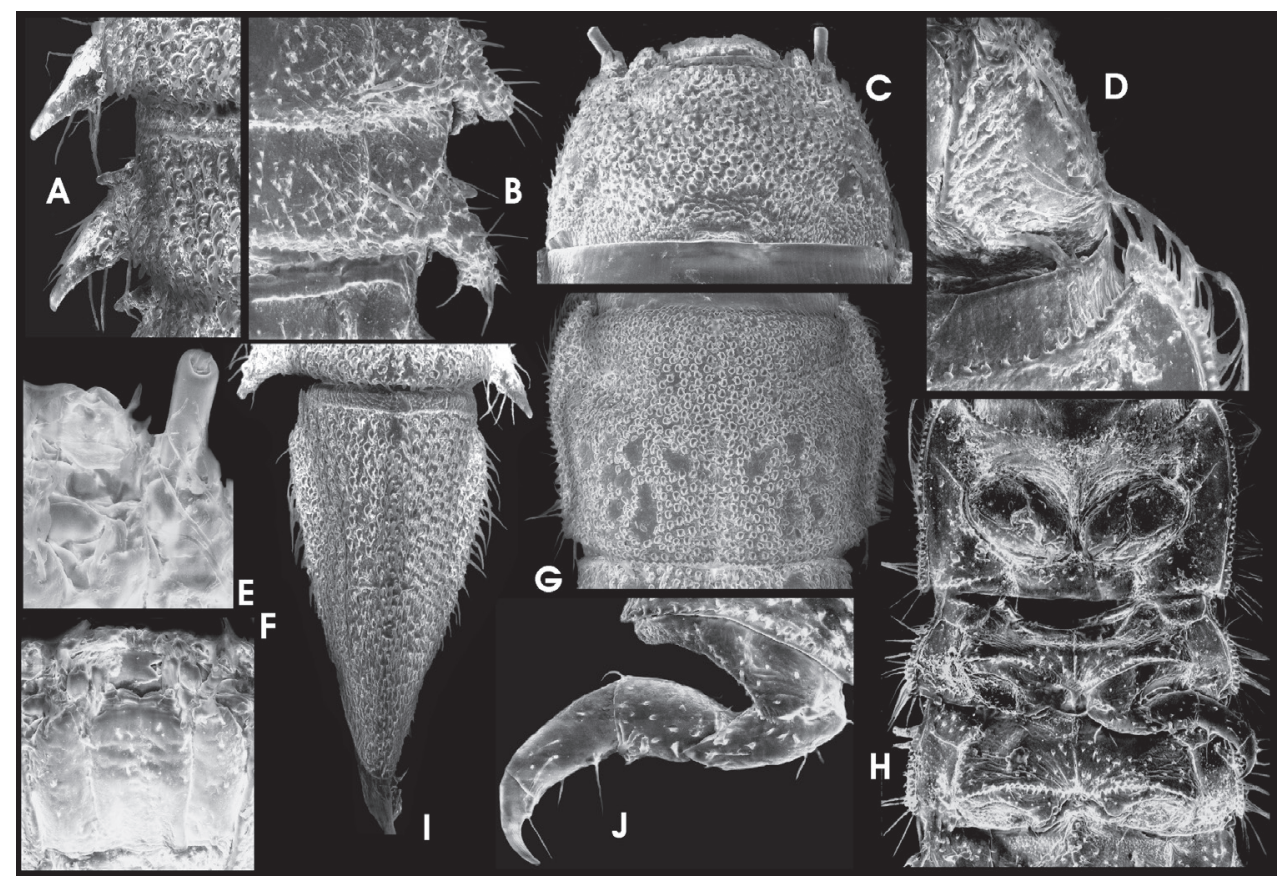

Figure 15. Ancyronyx schillhammeri Jäch, 1994, larva (SEM photographs) not to scale): A detail of abdominal segments II-III, dorsal, with posterolateral projections and spiracles B detail of abdominal segments VI-VII, ventral, with posterolateral projections and spiracles $\mathbf{C}$ head, dorsal $\mathbf{D}$ detail of head and prothorax, ventral $\mathbf{E}$ antenna, ventral $\mathbf{F}$ maxillae and labium, ventral $\mathbf{G}$ pronotum with signa, dorsal $\mathbf{H}$ thorax, ventral I abdominal segment IX, dorsal J midleg, ventral.

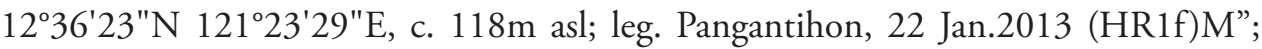

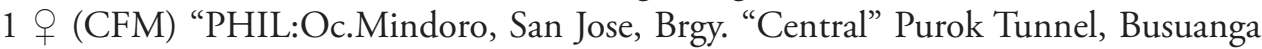
River; rural,cogon gras roots, riffle \& run, c.73 m asl., c. $12^{\circ} 27^{\prime} 51^{\prime \prime} \mathrm{N} 121^{\circ} 02^{\prime} 08^{\prime E}$; 07.VI.2012 leg. Freitag \& Pangantihon (330b)M".

Larval diagnosis (based on a single presumably sixth instar specimen). Colour in last instar larva predominantly brown as in Fig. 9; dorsal head darkest to almost black at pronotal disc; lateral head, antennae, anterior and lateral pronotal margins, legs (except for tip of claw), lateral abdominal segment margins and conical projections, posterior abdominal tip and areas around the sagittal line (especially thoracic area) distinctly paler, yellowish to pale brown. Ventral side entirely pale except for pale brown gula, maxillae and labium; ventral part of genae conspicuously dark brown.

HW c. $0.60 \mathrm{~mm}$; entirely c. $3.8 \mathrm{~mm}$ long.

Body shape of the $A$. variegatus group type, generally very similar to that of $A$. procerus (comp. Freitag and Balke 2011: 72-75) in the external habitus, except for the following: Posterolateral projections (Figs 9, 15A, B) of abdominal segments IV-VIII slightly broader and stouter; spiracles distinctly larger, very prominent; entire lateral margin with distinct long trichoid setae; tubercles much more prominent (especially at dorsal side). 


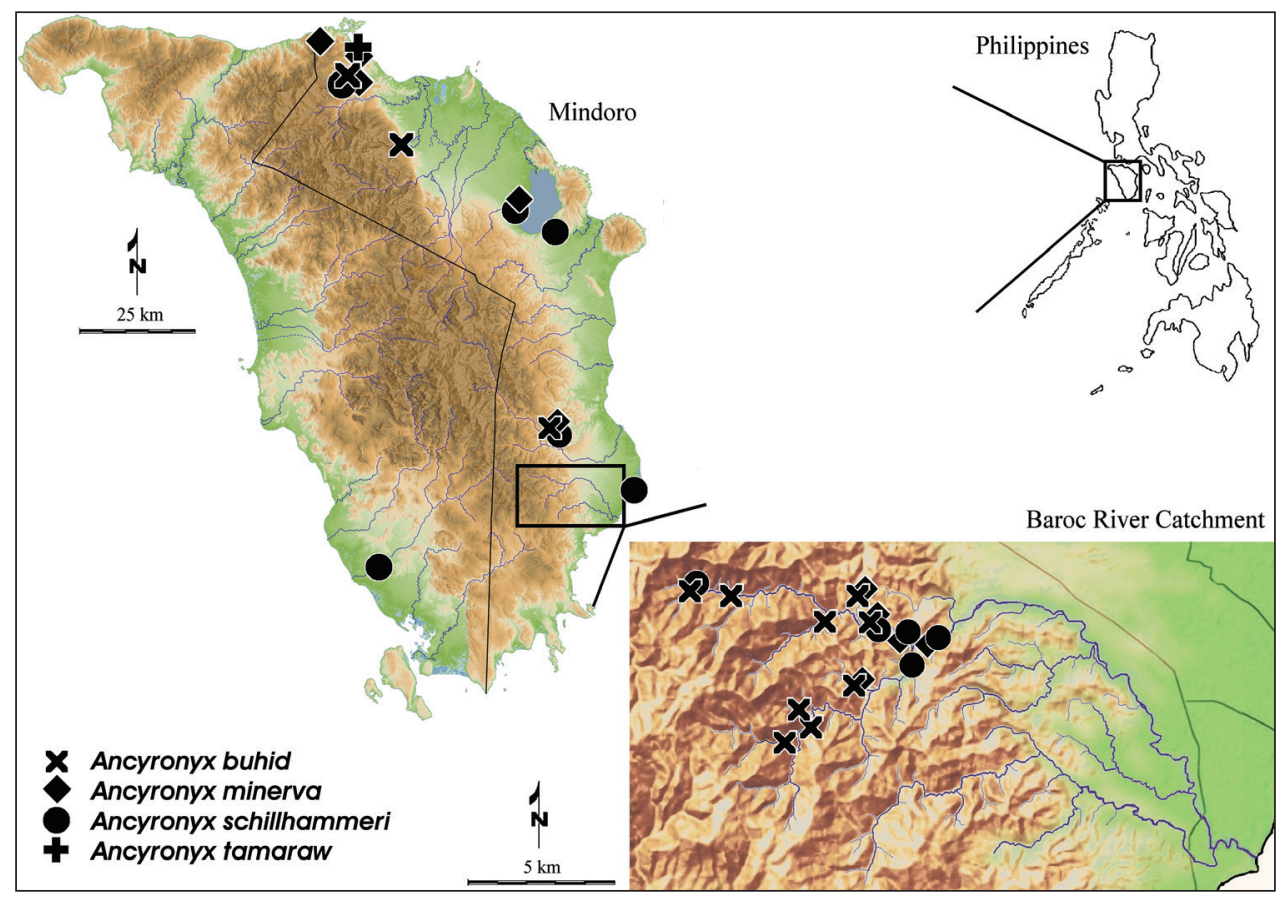

Figure 16. Collecting sites of the Ancyronyx species in Mindoro Island, including enlarged map of the Baroc River Catchment.

Head (Figs 15C-F) distinctly widest basally, slightly conical anteriad; without median pointed projection at frons; the pair of sublateral anterior projections between antenna and clypeus rather shallow (Fig. 15C). Frons moderately densely and equally covered with prominent setiferous tubercles; setae very short. Genae rugose, with irregular depressions, ridges, and scattered tubercles (Fig. 15D); lateral glabrous area with stemmata elongately subtriangular (Fig. 15D). Antenna (Fig. 15E) less than half as long as head. Scape short, slightly longer than wide, with subapical fringe of stout sensilla; pedicel cylindrical less than three times as long as scape and c. three times as long as wide, with few apical sensilla; flagellum and sensorium as in $A$. procerus. Ventral side (Fig. 15F) with well-developed longitudinal crests bordering the stipes. Labrum broad, c. 3.5 times as wide as long; lateroapical edges rounded; entire visible dorsal surface with small setiferous tubercles. Maxilla (Fig. 15E, F) almost as in A. procerus. Labium (Figs 15E, F) with mentum widest in apical half; pair of moderately long trichoid setae inserted sublaterally at anterior 0.3 ; some additional trichoid setae present at lateral margin in apical half; pair of apicolateral teeth inserted at a distinct subapical crenation; submentum straight, without conspicuous median ridge, apically broadly concave.

Prothorax (Fig. 15G, H) slightly wider than long; tergum with irregularly shaped and round signa in posterior half; median and submedian pairs clearly defined by bordering tubercles, not fused (Fig. 15G). Venter of prothorax (Fig. 15H) similar to that in 
A. procerus, but anterior sclerites distinctly shorter, oblique, not subtriangular; anterior margin with conspicuous setiferous tubercles; anterior and lateral sclerites partly fused near anterior prothorax margin; transverse sutures dividing the lateral sclerites distinctly ending before lateral margin. Venter of meso- and metathorax (Fig. 15H) with more conspicuous setiferous tubercles particularly at posterior margins of anterior sclerites.

Legs (Figs $15 \mathrm{H}, \mathrm{J}$ ) proportioned as in $A$. procerus, but tubercles and setae larger and more distinct. Subbasal tooth of claws long and trichoid, overreaching tip of claw.

Abdominal terga (Figs 9, 15A, B, I) with slightly depressed groove along sagittal line at least from $1^{\text {st }}$ up to $4^{\text {th }}$ segment; posterior terga margins with rim of squamose setae. Posterior venter margins with rim of trichoid setae. Segment IX (Fig. 15I) dorsally with shallow sagittal crest formed by densely arranged tubercles bearing large trichoid setae; apex widely rounded to slightly truncate; ventral side rugose, not glabrous. Operculum without longitudinal ridges, entirely rugose and covered with conspicuous scattered setae.

Larval differential diagnosis. The larvae of Ancyronyx schillhammeri are easily distinguishable from all other known Ancyronyx larvae of Mindoro by their larger size, the somewhat dorsoventrally depressed habitus, the much larger and protruding posterolateral appendages, as typical for the $A$. variegates species group. Among this species group, it resembles the larva of $A$. procerus in colour, but can be clearly distinguished by the absence of the pointed projections at median frons, the more shallow projections between antenna and clypeus, the larger and more protruding spiracles, the conical head shape, and the surfaces of head, thorax, and abdomen that are densely covered with larger tubercles bearing long conspicuous setae. From A. helgeschneideri it is easily distinguishable by the darker colour, the pale dorsosagittal stripe, the dark dorsal abdominal segment IX and the broader and conical head.

Distribution. Only known from Oriental Mindoro and one locality of Occidental Mindoro near San Jose.

Ecology. Ancyronyx schillhammeri occurs exclusively on submerged wood. Decaying pale light woods appear to be preferred by the species. At the sites of the Baroc River catchment, which were sampled regularly throughout the year, the abundance of this species was found to increase distinctly towards the end of the dry season (February to April) and declines rapidly with the beginning rainy season, presumably due to wash out. It is found in both habitat types: clean, cool and torrent rhithral creeks and rivers as well as warm, mesosaprobic lowland streams. This suggests less specific ecological requirements in terms of stream hydraulics, water temperature, and water quality.

\section{Key to the adult Ancyronyx species of Mindoro}

1 Elytra with yellowish "X"-shaped colour pattern (Fig. 8); combined length of pronotum and elytra $(\mathrm{CL}) \geq 1.8 \mathrm{~mm}$; legs very long $(\geq 1.2$ times of body length)

A. schillhammeri

- $\quad$ Elytra with four isolated yellowish colour patches; $\mathrm{CL} \leq 1.4 \mathrm{~mm}$; legs long to

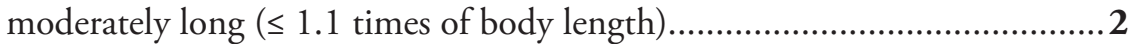


2 Body about half as wide as long (CL/EW c. 2.0), elytral shoulder distinctly wider than pronotum; posterior yellowish elytral patches more or less round, not distinctly elongate. A. bubid

- $\quad$ Body less than half as wide as long $(\mathrm{CL} / \mathrm{EW} \geq 2.2)$, elytral shoulder about as wide as pronotum; posterior yellowish elytral patches elongate, distinctly longer than wide ........................................(A. minerva species subgroup) 3

3 Pronotum anteriorly with transverse white to yellowish band; femora entirely dark coloured; anterior yellowish elytral patches large, extending over more than $3 / 4^{\text {th }}$ of elytral width (Fig. 2)....

A. minerva

- $\quad$ Pronotum entirely dark, without transverse band; femora predominantly yellowish coloured; anterior yellowish elytral patches small, extending over $1 / 2$ or less of elytral width (Fig. 3)

A. tamaraw

\section{Key to the larvae of Ancyronyx species of Mindoro}

1 Body flattened dorsoventrally (depressed), only slightly vaulted. Posterolateral abdominal projections large, conical, with tip posterolaterad directed. Dorsal colour predominantly dark brown, with distinct pale sagittal stripe in anterior half (Fig. 9).

A. schillbammeri

- $\quad$ Body spindle-shaped, elongate, subsemicircular in cross section. Posterolateral abdominal projections small, lobate, with tip posteriad directed. Predominant dorsal colour brown, with transverse pale yellowish bands or dots, without any pale longitudinal stripe (Figs 5-7).

2 First abdominal segment almost entirely yellowish, appearing as an obvious pale band. Dark portion of the pronotum medially extended anteriad, yellowish anterior pronotal band medially narrower. (Fig. 7) .... A. bubid

- $\quad$ First abdominal segment almost entirely brownish dark, no obvious pale band present at the dorsal abdomen. Anterior pronotal yellowish band regularly shaped or extending medially, not narrower along the midline (Figs 5-6)..... (A. minerva species subgroup) 3 Anteriomedian portion of the dorsal head yellowish pale, surrounded by dark areas. Last abdominal segment c. 2.3 times as long as wide, with pale apical and median areas and distinctly dark portion inbetween (Fig. 6).....

A. tamaraw

- $\quad$ Entire dorsal head disc brownish dark. Last abdominal segment c. 2.2 times as long as wide, any pale dorsal colour pattern lacking or limited to tip (Fig. 5)..

\section{Updated check list of the Philippine species of Ancyronyx}

1. Ancyronyx bubid Freitag, 2013 (Mindoro)

2. Ancyronyx helgeschneideri Freitag \& Jäch, 2007 (Palawan, Busunga) 


\author{
3. Ancyronyx minerva Freitag \& Jäch, 2007 (Palawan, Mindoro) \\ 4. Ancyronyx minutulus Freitag \& Jäch, 2007 (Palawan) \\ 5. Ancyronyx montanus Freitag \& Balke, 2011 (Palawan) \\ 6. Ancyronyx patrolus Freitag \& Jäch, 2007 (Palawan, Busuanga) \\ 7. Ancyronyx procerus Jäch, 1994 (Busuanga, Borneo, Vietnam) \\ 8. Ancyronyx pseudopatrolus Freitag \& Jäch, 2007 (Palawan) \\ 9. Ancyronyx punkti Freitag \& Jäch, 2007 (Palawan) \\ 10. Ancyronyx schillhammeri Jäch, 1994 (Mindoro) \\ 11. Ancyronyx sophiemarie Jäch, 2004 (Sibuyan) \\ 12. Ancyronyx tamaraw Freitag, 2013 (Mindoro)
}

\title{
Discussion
}

During the last two decades, the Philippine Islands have received increasing attention in biodiversity research, not least because they are classified as a major biodiversity hotspot in global scale (Myers et al. 2000). However, for several taxa including Elmidae and other freshwater macroinvertebrates, it still requires substantial efforts to record and to describe the majority of species and their distribution.

Four species of Ancyronyx are now recognised and formally described from Mindoro Island based on the study of a copious collection of museum specimens and the material retrieved from a comprehensive survey of the Baroc River Catchment in southern Mindoro. Only one of them, A. minerva, is recorded beyond Mindoro. A. schillhammeri and A. buhid appear to be endemic to the island. The high rate of island endemism reflects the biogeographic history of the island. Mindoro is a remnant of a fragment of the Eurasian continental margin and is not part of the Luzon arc of islands of marine volcanic origin (Hall 1998). Despite its recent close vicinity to Luzon, the two islands remained largely isolated in the Quaternary, even during Pleistocene when low sea levels have formed land bridge interconnections of several Philippine islands, but presumably Greater Palawan, Mindoro, and Greater Luzon remained separated based on Pleistocene sea-level low stands represented by the $120 \mathrm{~m}$ isobath (Sathiamurthy and Voris 2006).

Therefore, it requires more in depth phylogenetic and biogeographic studies to explane the distribution of $A$. minerva at both sides of the Mindoro Strait.

The phylogenetic relationship of $A$. buhid with other members of the genus is still ambiguous. Several taxa (probably new species) from the Philippines and Sulawesi that resemble $A$. buhid still await their description (unpublished material of the author and at NMW). After this material has undergone detailed study and molecular genetic analysis sound conclusions might be drawn.

The fact that Ancyronyx (and very most other Elmidae) live permanently under water and respire by a microplastron (Kodada and Jäch 2005) makes them sensitive to water pollution. The vivid and specific colour patterns of adult Ancyronyx species enabling an easy identification, as well as the availability of regional identification keys for both, larvae and adults, allow their potential use as bioindicators. Among the 
species of Mindoro, A. schillhammeri was recorded from clean to moderately polluted streams making it unsuitable as a bioindicator. The remaining Mindoro species seem to be ecologically adapted to clean and rather undisturbed waters. However, Ancyronyx tamaraw is too rare to serve as good bioindicators and A. minerva is occasionally detected in slightly polluted streams in low abundances (Freitag and Pangantihon 2010), suggesting a low indicator strength. Therefore, A. bubid in particular has the highest potential value to be used as saprobic indicator. Its frequent occurrence in suitable habitats and the easy identification by the distinguishing elytral colour pattern and broad elytral shoulders in adults, as well as the unique yellow abdominal pattern in larvae, make it a suitable tool for biomontoring, even for non-entomologists. However, ecological evaluations of larger scale are needed to confirm these preliminary findings.

\section{Acknowledgements}

Special thanks are due to Research Assistant Mr. Clister V. Pangantihon for his significant support during the field sampling at the Baroc River, preliminary sorting and labelling of the collected material and Dr. Michael Balke for providing access to his laboratory facilities at ZSM for molecular genetic analysis.

The project was kindly funded by PHERNet, a program of the Philippine Commission of Higher Education (CHED). Financial support was also kindly provided by an Ateneo de Manila University Loyola Schools Scholarly Work Grant (SOSE 8 2012). A fund for open access publication of this paper was granted by the "Encyclopedia of Life (EOL) Open Access Support Project" (EOASP).

Field sampling of the Baroc River Catchment Survey were made possible by the permission and support of the PENRO Oriental Mindoro, Calapan, SENRO Roxas, Municipal Government of Roxas, and the National Commission for Indigenous People (NCIP). The author wants to express his deep gratitude to Brg. San Vicente, Roxas, especially Captain Ronel S. Sescar, and all Brgy. Kagawats and Tanods that warmly welcomed the Ateneo team, guided the expeditions and provided accommodation. Many thanks are also due to all members of the Buhid communities of Tagaskan and Tauga Diit who gave official permission (FPIC \& MOA) for the field sampling in their ancestral lands, and guided and accommodated the excursion participants.

Furthermore, the author wishes to express his gratitude to the curators of the World Water Beetle Collection \& Research Centre at NMW, Dr. Manfred A. Jäch and the Coleoptera section of ZMUC, Dr. Alexej Solodovnikov, for access to their material collections and the loan of specimens. Sincere thanks are due to Dr. Jäch and an anonymous reviewer for their helpful comments on the manuscript. 


\section{References}

Agencourt Bioscience (2006) Agencourt CleanSEQ Dye-Termintor Removal, protocol 000600v32. Agencourt Bioscience Corporation, Beverly, 12 pp.

Ambal RGR, Duya MV, Cruz MA, Coroza OG, Vergara SG, de Silva N, Molinyawe N, Tabaranza B (2012) Key Biodiversity Areas in the Philippines: Priorities for Conservation. Journal of Threatened Taxa 4 (8): 2788-2796. doi: 10.11609/JoTT.o2995.2788-96

Baraclough TG, Hogan JE, Vogler AP (1999) Testing whether ecological factors promote cladogenesis in a group of tiger beetles (Coleoptera: Cicindelidae). Proceedings of the Royal Society of London B 266: 1061-1067. doi: 10.1098/rspb.1999.0744

Brown HP (1972) Aquatic dryopoid beetles (Coleoptera) of the United States. Biota of freshwater ecosystems identification manual no. 6. Water Pollution Control Research Series, EPA, Washington D.C., 82 pp.

Curtis J (1830) British Entomology; being illustrations and descriptions of the genera of insects found in Great Britain and Ireland: Containing coloured figures from nature of the most rare and beautiful species, and in many instances of the plants upon which they are found. London, vol. 7: 290-337.

Erichson WF (1847) Naturgeschichte der Insecten Deutschlands. Nicolaische Buchhandlung, Berlin, 968 pp.

Freitag H (2012) Ancyronyx jaechi sp.n. from Sri Lanka, the first record of the genus Ancyronyx Erichson, 1847 (Insecta: Coleoptera: Elmidae) from the Indian Subcontinent, and a world checklist of species. Zootaxa 3382: 59-65. http://www.mapress.com/zootaxa/2012/f/z03382p065f.pdf

Freitag H, Balke M (2011) Larvae and a new species of Ancyronyx Erichson, 1847 (Insecta, Coleoptera, Elmidae) from Palawan, Philippines, using DNA sequences for the assignment of the developmental stages. ZooKeys 136: 47-82. doi: 10.3897/zookeys.136.1914

Freitag H, Jäch MA (2007) The genus Ancyronyx Erichson, 1847 (Coleoptera, Elmidae) in Palawan and Busuanga, (Philippines) with description of six new species. Zootaxa 1590: 3759. http://www.mapress.com/zootaxa/2007f/z01590p059f.pdf

Freitag H, Pangantihon C (2010) Aquatic Coleoptera and Heteroptera of the Lake Naujan National Park, Mindoro Oriental, the Philippines. Philippine Scientist 47: 126-173. http:// www.philjol.info/philjol/index.php/PSCI/article/view/2424

Hadley A (2008) http://hadleyweb.pwp.blueyonder.co.uk/CZM/combinezm.htm Version of $18^{\text {th }}$ April 2008.

Hall R (1998) The plate tectonics of Cenozoic SE Asia and the distribution of land and sea. In: Hall R, Holloway JD (Eds) Biogeography and Geological Evolution of SE Asia. Backhuys Publishers, Leiden, 99-131.

Hall TA (1999) BioEdit: a user-friendly biological sequence alignment editor and analysis program for Windows 95/98/NT. Nucleic Acids Symposium Series 41: 95-98.

Hilsenhoff WL (1982) Using a biotic index to evaluate water quality in streams. Wisconsin Department of Natural Resources Technical Bulletin 132: 22 pp.

Hinton HE (1941) New genera and species of Elmidae. Transactions of the Royal Entomological Society of London 91(B) (3): 65-104. 
Jäch MA (1982) Neue Dryopoidea und Hydraenidae aus Ceylon, Nepal, Neu Guinea und der Türkei. (Col.). Koleopterologische Rundschau 56: 89-114.

Jäch MA (1994) A taxonomic review of the Oriental species of the genus Ancyronyx Erichson,

1847 (Coleoptera, Elmidae). Revue suisse de Zoologie 101 (3): 601-622. http://biostor. org/reference/ 115102

Jäch MA (2004) Descriptions of two new species of Ancyronyx Erichson (Insecta: Coleoptera: Elmidae). Annalen des Naturhistorischen Museums in Wien 105 B (2003): 389-395.

Kodada J, Jäch MA (2005) 18.2. Elmidae Curtis, 1830. In: Beutel RG, Leschen RAB (Eds) Handbook of Zoology, Volume IV (Part 38), Coleoptera, Beetles, Volume 1: Morphology and Systematics (Archostemata, Adephaga, Myxophaga, Polyphaga partim). Walter de Gruyter, Berlin, New York, 471-496.

Moog O, Jäch MA (2003) Elmidae. In: Moog O (Ed) Fauna Aquatica Austriaca, edition 2002. Wasserwirtschaftskataster, Bundesministerium für Land- und Forstwirtschaft, Umwelt und Wasserwirtschaft, Wien, 68 pp.

Myers N, Mittermeier RA, Mittermeier CG, da Fonseca GAB, Kent J (2000) Biodiversity hotspots for conservation priorities. Nature 403: 853-858. doi: 10.1038/35002501

Ong PS, Afuang LE, Rosell-Ambal RG (Eds) (2002) Philippine Biodiversity Conservation Priorities: A Second Iteration of the National Biodiversity Strategy and Action Plan. Department of Environment and Natural Resources -Protected Areas and Wildlife Bureau, Conservation International Philippines, Biodiversity Conservation Program University of the Philippines Center for Integrative and Development Studies, and Foundation for the Philippine Environment, Quezon City, Philippines, 113pp.

Ronquist F, Teslenko M, van der Mark P, Ayres D, Darling A, Höhna S, Larget B, Liu L, Suchard MA, Huelsenbeck JP (2012) MrBayes 3.2: Efficient Bayesian phylogenetic inference and model choice across a large model space. Systematic Biology 61 (3): 539-42. doi: $10.1093 /$ sysbio/sys029

Sathiamurthy E, Voris HK (2006) Maps of Holocene Sea Level Transgression and Submerged Lakes on the Sunda Shelf. The Natural History Journal of Chulalongkorn University, Supplement 2: 1-43.

Simon C, Frati F, Beckenbach A, Crespi B, Liu H, Flook P (1994) Evolution, weighting and phylogenetic utility of mitochondrial gene sequences and a compilation of conserved polymerase chain reaction primers. Annals of the Entomological Society of America 87: 651-702.

Tavaré S (1986) Some probabilistic and statisical problems on the analysis of DNA sequences. Lectures in Mathematics in the Life Sciences 17: 57-86.

Thompson JD, Higgins DG, Gibson TJ (1994) CLUSTAL W: improving the sensitivity of progressive multiple sequence alignment through sequence weighting, position-specific gap penalties and weight matrix choice. Nucleic Acids Research 22: 4673-4680. doi: $10.1093 / \mathrm{nar} / 22.22 .4673$

Qiagen (2002) DNeasy Tissue Kit Handbook 05/2002. Hilden, Germany, 43 pp. 